\title{
Protectionism Indices for Non-Tariff Measures: An Application to Maximum Residue Levels
}

\author{
Yuan Li, John C. Beghin
}

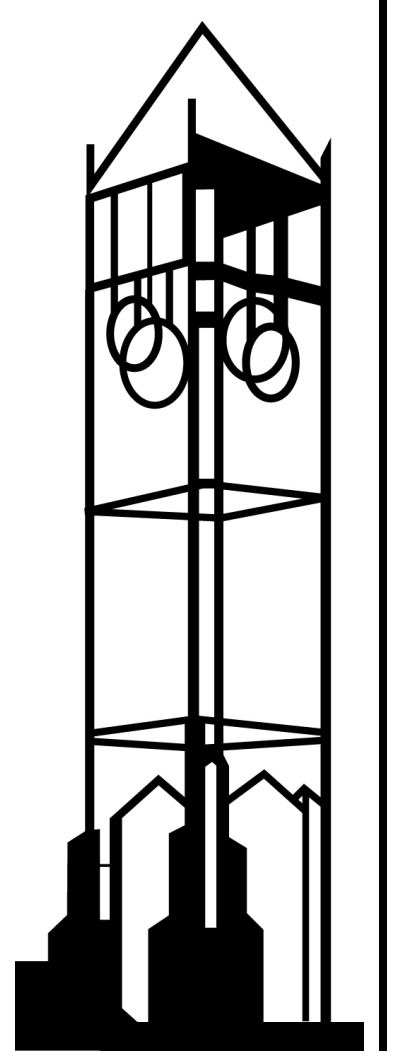

Working Paper No. 12013

July 2012

\section{IOWA STATE UNIVERSITY}

Department of Economics

Ames, lowa, 50011-1070 


\title{
Protectionism Indices for Non-Tariff Measures: \\ An Application to Maximum Residue Levels \\ Yuan Li (T-Mobile) \\ John C Beghin* (Iowa State University)
}

Revised December 24, 2013

\begin{abstract}
We propose aggregation indices of Non-Tariff Measures (NTMs) to quantify their protectionism relative to international standards of stringency. We apply the indices to national Maximum Residue Limit (MRL) regulations on pesticides and veterinary drugs affecting agricultural and food trade and using a science-based criteria embodied in Codex Alimentarius international standards. The approach links two streams of the NTM literature, one concerned with the aggregation of various NTMs into operational indices for econometric and modeling purposes, and the other attempting to evaluate the protectionism of NTMs. The data used in the application come from a large international dataset on veterinary and pesticide MRLs and CODEX MRL standards for a large set of countries.
\end{abstract}

JEL code: F13, Q17, Q18

Keywords: NTMs, non-tariff measures, barriers, protectionism, Maximum residue limit, MRL

\footnotetext{
* Yuan Li is a statistical consultant and economist at T-Mobile. John Beghin is Marlin Cole Professor of International Agricultural Economics in the Economics Department and the Center for Agricultural and Rural Development at Iowa State University. This paper is based on the second essay of Li's dissertation. The MRL data and computations in this version of the manuscript have been updated in spring 2012. We thank two referees and Editor Satoru Shimokawa for comments on an earlier draft of the manuscript, and Dermot Hayes, David Hennessy, John Schroeter, and Bo Xiong for comments and discussions. The usual disclaimer applies. Beghin acknowledges support from the Marlin Cole Fund at Iowa State University. Contact author: John Beghin: 383 Heady Hall. Economics and CARD. Iowa State University Ames IA 50011-1030. USA. Email: beghin@iastate.edu. Phone: 1515 294 5811. Fax: 1515294 0221. The score data is available from the authors upon request.
} 


\section{Introduction}

We fill a gap in the literature on empirical measures of protectionism of nontariff measures (NTMs) by proposing simple yet formal aggregation indices of NTMs. The indices measure the protectionism of Maximum Residue Limit (MRL) standards relative to science-based criteria embodied in international standards such as Codex Alimentarius. MRLs set limits on harmful substances, like pesticide residues, veterinary drug residues, and other harmful substances, that importing countries allow on similar imported and domestic products as implied by national treatment. MRLs are often substance, product, and country specific. Countries have a legitimate right to set science-based MRLs in presence of harmful risk. MRLs can also be used to impede trade to protect domestic producers rather than protecting health or the environment.

We link two streams of the NTMs literature, each addressing a specific problem. These two problems have been vexing and remain largely unresolved. One stream is concerned with the aggregation of various NTMs into meaningful indices, to characterize NTM regimes and to be used in econometric analyses of trade flows or to model and analyze policy impact (Disdier, Fontagné, and Mimouni (2008)). The other stream attempts to evaluate the protectionist nature of NTMs. Unlike tariffs for which the presumption is that they distort trade and welfare, NTMs may improve welfare (improvement in economic allocation of resources) because they address some market imperfection (Beghin et al. (2012)). So quantification, aggregation, and delineation of the potential protectionism of NTMs are a complex and important issue in the analysis of NTMs.

Empirical studies of NTMs almost inevitably involve quantification and aggregation of several policies. Unlike tariffs, a single policy type whose numerical values can be directly used and interpreted, NTMs cover a lot of intrinsically different policies. For example, a MultiAgency Support Team (MAST) of international organizations proposed a classification of 
NTMs, which consists of 16 major categories, including Sanitary and Phytosanitary (SPS) measures, Technical Barriers to Trade (TBT), other technical measures, price control measures, quantity control measures, etc. These NTMs can be qualitative and/or quantitative standards. For qualitative standards, like labeling, no numerical values can be directly used. Further, these qualitative policies affect different components of cost of production and marketing and cannot be easily aggregated into a single price equivalent. Evaluating the protectionist component of these numerous qualitative policies into a protectionist score is likely to remain a challenge. For quantitative NTM policies, we show that aggregation is a much more manageable task

Individual NTMs have been used empirically in a disaggregated fashion (Disdier and Marette (2010); Wilson and Otsuki (2004)). For qualitative standards, dummies are usually used to indicate the existence of such a standard. For quantitative standards, like Maximum Residue Limits (MRLs), the numerical levels may be directly used in the model (Xiong and Beghin (2012)). However, a single disaggregated NTM has limited application. Usually, a myriad of standards work together to regulate the quality of a product, and picking just one of the NTMs may lead to subjective selection bias and a mischaracterization of the set of NTMs regulating the market under study. In addition, even if there is no bias, a single NTM is not exhaustive and may not be representative.

Based on that concern, researchers often aggregate regulations and standards in summary indicators (Winchester et al., 2012). Indices involve aggregating over different regulations and standards, like labeling and MRL, and/or aggregating over products of different importance. Indices have their own drawbacks, especially when they aggregate heterogeneous policies. Their interpretation may be difficult. The estimated impact of the index on trade cannot be traced back to a particular instrument type or policy and policy prescriptions are infeasible. Recent investigations focus on measuring the heterogeneity of NTMs regimes across countries and 
products. Kox and Lejour (2006) propose an index based on a binary indicator of NTMs similarity. Rau, Shutes, and Sclueter (2010) developed a heterogeneity index of trade (HIT) of NTMs that can be applied to binary, ordered, or quantitative NTMs. The HIT is non-directional which means it measures the bilateral dissimilarity of NTMs, but gives no information about the relative strictness of NTMs. This is a drawback as countries could be dissimilar by being more or less stringent and because the relative regulatory environment could be different (lax or stringent environments presumably easy or rather difficult to meet as it is increasing costly to meet stringency at the margin). Winchester et al. (2012) extend the HIT, to a directional HIT (DHIT) capturing the asymmetric stringency between two countries and apply it to MRL data in an investigation of bilateral trade of agricultural products. This is an improvement over the HIT as trade presumably flow more easily from more stringent locations to less stringent destinations rather than the opposite. Still the drawback about the relative lax or stringent regulatory environments remains; a difference of 5ppm around a 50ppm MRL is different from a $5 \mathrm{ppm}$ difference around a 10ppm MRL for a similar substance. Vigani, Raimondi, and Opler (2009), Drogué and DeMaria (2012), and Achterbosch et al. (2009) offer alternative scalar summary measures of dissimilarity of policies which still present either or both of these drawbacks.

An alternative to these heterogeneity indices, the frequency ratio is often used (Harrigan (1993); Fontagné, Mimouni, and Pasteels (2005); and Disdier, Fontagné, Mimouni (2008)). It calculates the coverage of NTMs of product categories relative to the total number of product categories of at aggregated level (say HS4 or HS2 digit) and weighted by production levels. Other aggregate or summary count proxies exist to provide an aggregate characterization of NTM regimes. These proxies do not provide much information on the stringency of NTM regimes (numerous lax NTMs, by count or frequencies, can be seen as more stringent than as a few exacting NTMs). See Li and Beghin (2012) for a systematic review of various NTM proxies 
and aggregators used in econometric investigations.

Traditionally many NTMs investigations have assumed NTMs impede trade (and implicitly decrease welfare) and rule out trade or welfare enhancing effects. However, it is increasingly recognized that market imperfections such as asymmetric information and production and consumption externalities abound and NTM policy interventions could increase welfare and may be trade-impeding or trade enhancing while increasing welfare (Beghin et al. 2012, Carrère and De Melo, 2011; Disdier et al, 2008; and Disdier and Marette, 2010). NTMs may also be protectionist of course. Nevertheless, some agnostic priors on their protectionist nature ought to prevail. The empirical literature actually shows numerous cases of tradeenhancing NTMs (see Li and Beghin (2012) for a systematic review of that literature). There is no simple mapping between NTMs, their stringency, and their trade and welfare effects in presence of market imperfections.

To complicate further, market imperfections may justify some NTMs but do not exclude protectionism because the level of the chosen measure may be overly stringent, hence, protectionist by creating unnecessary frictions in trade. This is an increasing preoccupation in policy forums (Disdier and van Tongeren (2010)). Several investigations correlate frequency and trade frictions, without formalizing what is protectionism. For example, Disdier and van Tongeren (2010) make the conjecture that protectionism is responsible for some variance of incidence of NTMs across agri-food products. Disdier, Fontagné, Mimouni (2008) posit that protectionism may exist when a SPS measure is enforced by only a few countries. Not looking explicitly at protectionism but rather at trade frictions, Winchester et al. (2012) investigate how bilateral stringency differences in NTMs affect bilateral trade. Reducing stringency differences to common lower stringency levels would increase trade; the welfare (allocative efficiency) grounds to do so are less clear, unless protectionism is presumed to prevail in the most stringent 
countries. These "conjectures" are intuitive, but lack formalism which we attempt to provide here.

\section{Formalizing protectionism}

When defining protectionism of NTMs one can start with the simple science-based test. In absence of scientific evidence establishing market imperfections or risk, a NTM is protectionist. ${ }^{1}$ In presence of established risk or imperfections, identifying protectionism is more cumbersome.

More conceptually, Fischer and Serra (2000) provide a formal criterion for gauging protectionism in presence of market imperfection. They conceptually analyze the protectionism behavior of a local social planner (LSP) setting up a quality standard to lower a negative consumption externality. The authors define a standard as protectionist if its optimum level is higher under a local LSP than under a global social planner treating all firms competing for the domestic market (foreign and domestic firms) as purely domestic. They find that when there a negative consumption externality the LSP always set the optimum domestic standard at a higher (protectionist) level than the level chosen by the global planner. The argument would be valid for a negative production externality as well. The Fisher and Serra results hinge on the domestic firms being more efficient at meeting the quality standard than foreign firms are. Marette and Beghin (2010) show that if foreign firms are much more efficient at meeting the standard, the domestic LSP will choose an anti-protectionist standard, lower than the global standard. Berti and Falvey (2009) extend the analysis of Fisher and Serra and incorporate rent seeking industries influencing the way the LSP sets standards. They investigate how rent-seeking and socially optimum standards vary from autarky to free trade. Rent-seeking under free trade between two countries promotes the harmonization of standards that were heterogeneous under autarky. Finally, earlier on, Baldwin (1970) defines a NTM as protectionist whenever it lowers global real

\footnotetext{
${ }^{1}$ There is a caveat of the precautionary principle which lets a country introduce a NTM while establishing the science. A precautionary policy without the pursuit of evidence is protectionist according to the WTO.
} 
income. The latter criteria could conceptually accommodate cases with market imperfections.

These conceptual efforts provide clear definitions of protectionism. However, they are difficult to operationalize in realistic empirical applications when many NTMs are imposed at once and because informational requirements are extensive. The issue of an aggregator lurks again in presence of many NTMs. Further, the Fisher and Serra criterion is not directly applicable when the supply is only made of foreign firms as in the case of tropical exports to most of the Northern hemisphere (e.g., the EU peanut market). The Baldwin criterion is also difficult to implement in real empirical cases given the "world" dimension of the criteria.

The World Trade Organization (WTO) does not set standards but strongly encourages countries to use internationally accepted science-based standards, like Codex Alimentarius standards whenever available. ${ }^{2}$ However, the WTO allows its members to set their own standards away from international ones, as long as their individual standards are science based, nondiscriminating, and least trade restrictive (WTO Doha Ministerial (2001)). The issue of "appropriate level of protection" is still under discussion, and the WTO has not yet disambiguated what this means practically. Yet the science-based argument is a corner stone to fight protectionism and has led to several ruling by the WTO against policies in the EU, Japan, and Australia which could not be justified using scientific evidence (see WTO dispute cases DS245, DS367, and DS26).

In the next section, we propose indices of NTM protectionism based on the departure of their stringency from that of international science-based standards. We consider MRL measures, which are quantitative standards and give us a basis for comparison and aggregation. We use the Codex Alimentarius MRL standards as the non-protectionist science-based reference level. MRLs that exceed Codex levels are defined to be protectionist or "excessively stringent" beyond

\footnotetext{
${ }^{2}$ The WTO's SPS Agreement says"to harmonize sanitary and phytosanitary measures on as wide a basis as possible, Members shall base their SPS measures on international standards, guidelines or recommendations". The Agreement names Codex as the standard-setting organization for food safety.
} 
international norms, a simple criterion. It extends naturally from the WTO recommendation to use international standards. We also limit our analysis to science-based situations for each of which an international standard exists.

\section{Defining Protectionism Indices}

Different aggregation levels have specific purposes. A measure of the protectionism for a given importer and given good provides detailed information for importers by commodity. This aggregator is useful for cross section (goods and countries) econometric investigations. It can be used in gravity equations to characterize the SPS policy regime, along with tariffs and farm subsidies and econometrically estimate the impact of these policies on detailed sectoral trade. These commodity- in-country scores are the building blocks of the other two aggregation scores, aggregating over countries to establish an average protectionist score per commodity or aggregating over all considered goods by country to establish country protectionism in these SPS regulations. These country aggregate indices allow us to assess and rank countries by their relative MRL protectionism. These indices could also be compared to summary protection measures via tariffs and farm subsidies to analyze the policy composition of protectionism.

We define an importer's MRL to be protectionist when its stringency exceeds the corresponding science-based international MRL. If an importer's MRL is higher than the corresponding international MRL, then we deem the MRL non-protectionist. The aggregation over a multitude of substances (and goods) provides robustness to the indices. An "unintended" accidental protectionist MRL will be swamped by other non-protectionist MRLs included in the three indices proposed below if a country is mostly non-protectionist.

Define $M_{i j k_{(j)}}$ the maximum residue level of importer $i$, for good $j$, and harmful substance $k_{(j)}$; and let $M_{i n t l, j k_{(j)}}$ be the international maximum residue level for the same good and 
harmful substance. Denote total number of importers as $I$, total number of goods as $J$, and total number of chemical/pesticides applied to product $j$ as $K_{(j)}$. To each of the three aggregations stated above, we propose the following indices, the commodity-in-country index $S_{i j}$, country index $S_{i}$, and product index $S_{j}$ :

$$
\begin{gathered}
S_{i j}=\frac{1}{K_{(j)}}\left(\sum_{k_{(j)}=1}^{K_{(j)}} \exp \left(\frac{M_{i n t l, j k_{(j)}}-M_{i j k_{(j)}}}{M_{i n t l, j k_{(j)}}}\right)\right) \\
S_{i}=\sum_{j=1}^{J} \sum_{k=1}^{K_{(j j}} \frac{1}{K_{(j)}}\left(\sum_{j=1}^{J} \exp \left(\frac{M_{i n t l, j k(j)}-M_{i j k_{(j)}}}{M_{i n t l, j k_{(j)}}}\right)\right) \times w_{i j}, \\
\text { and } S_{j}=\sum_{i=1}^{I} \sum_{k=1}^{K_{(j)}} \frac{1}{K_{(j)}}\left(\sum_{j=1}^{J} \exp \left(\frac{M_{i n t l, j k(j)}-M_{i j k_{(j)}}}{M_{i n t l, j k_{(j)}}}\right)\right) \times w_{i j}^{\prime},
\end{gathered}
$$

where $w_{i j}$ is the weight assigned to product $j$ when we aggregate over products for given country $i$ in country index $S_{i}$. Ideally, weights should reflect the dead-weight loss associated with each product in aggregation over products for a given country. However, dead-weight loss data are not readily available, and we consider 3 alternatives to mitigate this issue. First, we use unweighted scores (all weights are equal fractions summing up to unity). These equal weights have the interesting property that they provide country and commodity rankings identical to those obtained by using world-average trade weights to all countries. Second, we use import value as the basis of the weights $w_{i j}$. Third and last, we consider neighboring countries' trade weights to avoid the potential bias which could exists if some stringent MRL choke trade in a given country. Neighboring countries have their own policies and their trade patterns.

The country weight $w_{i j}^{\prime}$ is the weight assigned to country $i$ when we aggregate over countries for given product $j$ to obtain total protection in that product with product index $S_{j}$. More specifically, for the trade based indices we have $w_{i j}=I M_{i j} / \sum_{j=1}^{J} I M_{i j}$ and $w_{i j}^{\prime}=I M_{i j} / \sum_{i=1}^{I} I M_{i j}$, 
where $I M_{i j}$ is the import value of country $i$ (or its neighbors) for total trade of product $j$. As shown, the weights are normalized to sum up to one. Below, we refer to the traded scores based on own trade values as "trade-weighted" and we refer to the unweighted scores as "equallyweighted" or "unweighted." We refer to neighbor-weighted scores when we use neighbors' trade weights to establish scores.

To summarize, index $S_{i j}$ measures the protectionism of the MRLs for a given product and importer, aggregating over hazardous substances; $S_{i}$ measures the protectionism of MRLs for a given importer, aggregating over substances and products; and $S_{j}$ measures the protectionism of MRLs for a given product, aggregating over substances and importers.

\section{Properties of the indices}

By design, the indices have the following properties. They are unit free and invariant to scale since they tally and aggregate deviations in MRL in relative terms (\%). The units used for MRLs are irrelevant as long as Codex MRL and the MRL in question are in the same units. Increasing marginal difficulty of attaining stricter standards (convexity in protectionism) is also imposed by using exponential weights. That is the cost of stringency beyond Codex increases at an increasing rate. We also have invariance to regulation intensity, monotonicity (non-decreasing in MRL stringency of different countries, same product and same harmful substance, other things equal), and lower and upper bounded.

First, we subtract the importer's MRL from the international MRL, because, by the definition of protectionism, only the part of the importer's MRL that is more stringent than the international MRL contributes to protectionism. When the MRL is laxer than the international standard, it is anti-protectionist. MRLs have different scales, which could vary from 0.01 ppm(parts per million) to $10 \mathrm{ppm}$ or more. To make the index invariant to the scale of different residue levels, we scale the differences between importer and international MRLs by the 
international MRL. Second, the lower (i.e, stricter) the standard the harder it is for exporters to achieve. For example, some importers may relax all but one MRL above the international accepted level. But the one stringent MRL may become tough to achieve. By taking the exponential of the protectionism contributing part of the MRL, we put more weight on the MRLs that are relatively more stringent.

Third, the number of substances regulated varies by products in many cases. In our application, this number of substances ranges from over a hundred to below 10. For example, the United States has established 107 pesticide MRLs for apples, and only 7 pesticide MRLs for coconut. The different regulatory intensity is possibly due the heterogeneous popularity of products with consumers. By averaging the sum of protectionism scores of each pesticide by the total number of pesticides, we make the protectionism indices invariant the regulation intensity. This property is further analyzed later in the paper as the regulatory intensity may be confounded with some missing data issue.

Last, the indices are non-decreasing in stringency $\left(M_{i j k_{(j)}}\right.$ getting smaller) for different countries given the same $j, k_{(j)}$ and all other things being equal. If a country's standard is more stringent, its protectionist scores will be nondecreasing in that stringency. Note that the scores are bounded by 0 ("infinite" MRL) at the lower bound and $e \approx 2.72$ at the upper bound (zero MRL). A score of 1 indicate a non-protectionist policy (MRL at the Codex MRL). Scores larger than 1 indicate "protectionism" of policies as MRLs are more stringent than Codex on average, and scores below 1 indicate the "anti-protectionism," of policies as MRLs are laxer than Codex on average. $^{3}$

\footnotetext{
${ }^{3}$ In an earlier version, we truncated the indices below at 1 by constraining MRLs to have a score of 1 if they are not protectionist, including anti-protectionist MRLs. This truncation precludes having high and low scores offsetting each other. However, because we observed little offsetting in the data, we did removed the truncation. Avoiding truncation allows for anti-protectionism and provides a better measure of the variation in scores within a given
} 


\section{Application and Data Description}

The MRL data used here are publicly available and come from the USDA FAS International

MRL database (http://www.mrldatabase.com/) accessed on line in March 2012 (after a

substantial update). The database consists of pesticide MRLs and veterinary drug MRLs.

Pesticide and veterinary drug MRLs are maintained in two separate databases and their data

structures are different. We discuss the pesticide MRLs database first. We note that this database has large overlaps with the Homologa database maintained by the UK Department For Environment, Food, and Rural Affairs.

The pesticide MRLs database covers 341 products (Table 1), 19,486 (product by pesticide) pairs, and 83 countries, and has 1,617,338 records. Among the 83 countries covered by the pesticide MRLs database, 29 countries completely comply with Codex standards; 18 countries comply with EU standards; 7 countries defer to exporting countries standards; 5 countries comply with Gulf Cooperation Council (GCC) standards; and Mexico adopted U.S. standards. Finally, 22 out of 83 countries set their own standards only or partially combined with Codex or EU standards.

Table 1: Product categories in the pesticide database

\begin{tabular}{|l|l|}
\hline Category & Count \\
\hline Grains \& Oilseeds & 14 \\
\hline Poultry \& Eggs & 6 \\
\hline Dairy & 2 \\
\hline $\begin{array}{l}\text { Horticultural \& Tropical } \\
\text { Products }\end{array}$ & 313 \\
\hline Animal Products & 15 \\
\hline
\end{tabular}

\section{Pesticide MRL data issues and remedial steps}

This rich database has several shortcomings which we address as follows. First, there is some redundancy in the listed products (different names for a similar good or several names into a

index, but allows for protectionism and anti-protectionism offsetting each other within the index. The latter would be reflected in a large variance for the index. 
broad category). When we aggregate over products to calculate country-level protectionism indices, redundancy causes larger influence for the redundant products. Exact redundancy (several names for a commodity) is manually detected and deleted. Redundancy by commodity grouping is a bit more complicate (e.g., Beans with Bean Dry, Broad Bean Dry, Mung Bean, kidney Bean, and Lima Bean when Beans include Broad Beans, Mung Beans etc). Some countries specify their MRLs for specific kinds of beans (“Mung Mean”," Pink Bean”), but some other countries just specify MRL for "Beans" in general. We keep the redundant products of this kind, in order to make the product list consistent and comparable across countries but with the caveat in mind.

A second concern is that the MRL database only lists chemicals that are available to U.S. farmers. This problem also applies to the veterinary drug database. A foreign MRL for a product or chemical is only included in the database if there is a U.S. MRL for that product or chemical. Hence, the foreign country could be regulating other residues but we do not know for which chemical and the corresponding MRLs. This concern is limited because the U.S list is the most comprehensive list of chemicals across all countries. In addition, we compared the chemical list in the USDA data and that of Homologa (for 2008) from the UK Department for Environment, Foood, and Rural Affairs and the two lists are comparable, especially for chemicals for which Codex has an established MRLs. USDA has a slightly longer list, probably because of the more recent reference year. So we believe this concern is manageable.

The third problem with the database resides with non-established MRLs. This problem also applies to the veterinary drug database. Usually, the default MRLs defined by countries may apply when no MRLs are established. But there are rare cases when chemicals are exempt or banned. Since the database only includes the chemicals that the United States has positively listed and because Codex has also regulated residues for this substance, it is unlikely that these 
substances are considered exempt by other countries since both Codex and the US regulate them. In addition, it is difficult to find lists of banned chemicals maintained by other countries. We have no further information to distinguish when a non-established MRL means default, exempt, banned, or missing data. Because the exempt and banned cases are rare, we substitute nonestablished MRLs with individual country's default MRLs (see table 2). Missing data remain a concern. The USDA database was extensively updated in 2012 after its initial (2010) release with many non-established data being eventually updated by actual MRLs. Missing data have been greatly reduced.

Table 2: Default Values for non-established Pesticide MRLs

\begin{tabular}{|l|l|l|}
\hline $\begin{array}{l}\text { Default values for } \\
\text { non established } \\
\text { Pesticide MRLs }\end{array}$ & Countries & $\begin{array}{l}\text { Number of } \\
\text { Countries }\end{array}$ \\
\hline $0 \mathrm{ppm}$ & Australia, Taiwan & 2 \\
\hline $0.01 \mathrm{ppm}$ & $\begin{array}{l}\text { European Union, Norway, Malaysia, South Africa } \\
\text { Japan, Argentina }\end{array}$ & 5 \\
\hline $0.1 \mathrm{ppm}$ & Canada & 1 \\
\hline Codex & $\begin{array}{l}\text { Chile, China, Gulf Cooperation Countries (GCC), } \\
\text { Indonesia, India, South Korea, Singapore, Thailand, } \\
\text { Brazil, Russia, New Zealand, United Arab Emirates }\end{array}$ & 12 \\
\hline EU & Switzerland, Turkey & 2 \\
\hline
\end{tabular}

\section{The Veterinary database}

The original veterinary drug database covers 7 product groups (hogs, chickens, turkeys, sheep, cattle, milk, and eggs), 19 countries and/regions and international standards (Codex) and contains 8,820 records. The non-established MRLs are substituted with default values (table 3 ). However, for Chile, China, Hong Kong, Indonesia, Malaysia, Thailand, and Vietnam, we did not find their default veterinary drug MRLs. So we deleted the non-established MRLs from these countries. Since Chile and Indonesia only have non-established veterinary drug MRLs shown in the database, all of their veterinary drug MRLs are deleted unfortunately.

\footnotetext{
${ }^{4}$ The veterinary drug default for South Africa is $0.05 \mathrm{ppm}$

${ }^{5}$ We did not find the default MRL for Turkey, but assumed it to be EU MRLs.
} 
Unlike the pesticide MRLs database, which is a balanced country by (product and pesticide) panel data set, the veterinary data are unbalanced. Products and the veterinary drugs associated are different for different countries. To combine pesticide MRLs with veterinary drug MRLs, we matched the products based on the pesticide database. Due to the incompleteness of the second dataset, at the commodity level, veterinary drugs are included for some countries but not for other countries.

Table 3: Default Values for Non-established Veterinary Drug MRLs

\begin{tabular}{|l|l|}
\hline $\begin{array}{l}\text { Default Values for Non- } \\
\text { established Veterinary } \\
\text { Drug MRLs }\end{array}$ & Countries \\
\hline $0.01 \mathrm{ppm}$ & Japan \\
\hline $0 \mathrm{ppm}$ & $\begin{array}{l}\text { Australia, Canada, European Union, United States, } \\
\text { Taiwan, Norway }\end{array}$ \\
\hline Codex & $\begin{array}{l}\text { Colombia, Dominican Republic, Egypt, Guatemala, } \\
\text { Honduras, Peru, Philippines, Venezuela, }\end{array}$ \\
\hline Unknown & $\begin{array}{l}\text { Chile, China, Hong Kong, Indonesia, Malaysia, Thailand, } \\
\text { Vietnam }\end{array}$ \\
\hline
\end{tabular}

The products covered by the MRL databases are manually mapped into 6-digit or 4-digit Harmonized System classification (HS) (table available upon request). The mapping between the products listed in the MRL database and HS is not bijective. Correspondences exist both ways. One product could be mapped into multiple 6-digit HS code, and one 6-digit HS code could be mapped with more than one product in the MRL database, given that some products are very specific and others are broadly defined. Given the HS 6 or HS 4 digits codes, we compile the trade data from the United Nations Comtrade database. Trade weights, which are used in calculating trade weighted indices, are the average of trade values for all products falling under the same HS 6-digit (or 4-digit) category if more than one product are mapped to one HS 6-digit (or 4 digit) category. If one product is mapped to multiple HS 6-digit (or 4-digit) categories, we sum up trade values of the mapped HS categories.

We use the Codex MRL standards as the non-protectionism science-based reference 
levels. The WTO explicitly refers to Codex MRLs as the international SPS standards of choice. Codex standards are established using scientific expert advice and established science, and aims to protect consumer health and the environment. Codex MRL standards are set by the Codex Alimentarius Commission (CAC), which is a joint Food and Agriculture Organization (FAO) and World Health Organization (WHO) commission. Some Codex standard may not be established, and the reasons for that may be hard to determine. CAC may decide not to establish the MRL, or decide the chemical should not be allowed, or that the chemicals are not harmful, or it might be that the standard setting process is still undergoing. Codex MRLs are established through a multi-year process by the Codex Commission on Pesticide Residue (CCPR). Member countries nominate MRLs they wish to establish. It takes an average of two to four years for Codex to complete a standard (Roberts and Josling (2010)). However, Codex maintains a rather extensive list of chemical MRLs, and more than half of the countries in our dataset completely or partially defer to Codex standards as recommended by the SPS Agreement of the WTO.

Therefore, to avoid ambiguity in our investigation, we focus on the subset of products and chemicals for which Codex MRLs are established. For countries that have non-established standards for certain chemicals, we substitute their default values based on that individual country's default MRLs (see Table 2 and Table 3). In addition, since the GCC standards are not available in the database, we remove the 5 GCC countries from our sample.

The final combined MRL dataset for calculation in this paper consists of 273 products, 77 countries, and includes 411,304 records. The products represent about $62 \%$ of agricultural imports by these countries under HS $02,04,06-10,12$, and 15 . Note that the chemicals applied to each product may differ, and the set (product $\mathrm{x}$ chemicals) associated with different countries may vary due to the unbalanced veterinary drug data we mentioned above. In addition, we added EU-27 as a group, in addition to the individual EU countries. So, in total we have 77 countries 
(83 countries (all countries in the original MRL database), minus 5 excluded GCC countries, minus 2 data unavailable countries (Switzerland and Norway), plus one aggregate EU-27).

Our MRL application is relevant in the realm of NTMs. Comprehensive data on the precise composition and prevalence of NTMs do not exist. However, some order of magnitude is available. Based on survey data of the International Trade Center, the WTO estimates that TBT/SPS measures represent 59 percent of NTMs affecting agriculture (WTO 2012 pp 8). Within these measures the same WTO source states that SPS are the $1^{\text {st }}$ and $4^{\text {th }}$ most prominent NTMs faced by EU and US exporters based on 2009 data (WTO 2012, pp 114, and Martinez, Mora, and Signoret, 2009). A breakdown of SPS measures is not available, but quality standards and limits on residues and harmful substances are important and systematically identified as one of the major source of burdensome SPS measures (WTO 2012, pp 111-113). In our dataset, the share of Codex MRLs in the total number of MRLs is $27 \%$. Finally we note that other applications are possible for other SPS regulations like aflatoxin residues, and TBT standards such as heavy metal residues in toys.

\section{Results}

We calculated 21,021 country-by-product level protectionism scores $^{6}$ with non-established MRLs substituted with default levels (method 1) and 18,758 country-by-product level protectionism scores with non-established MRLs deleted (method 2). For each method, we then aggregated country-by-product scores to country level and product level with 2 sets of trade weights, and then equal weights.

\section{Country level results}

We have 50 trade-weighted country level indices and 77 equally-weighted country level indices

\footnotetext{
${ }^{6}$ Detailed results are available upon request.
} 
(available upon request). Note that the difference in number of countries is due to the availability of COMTRADE trade data. In addition, EU countries have the same EU standards and similar trade structures, so, instead of individual EU countries, we report for the aggregate EU-27. Mexico complies with U.S. standard, yet it has a slightly different protectionism score, which is caused by its own import structure leading to different weights in the indices' aggregation. We also report Taiwan's unweighted and neighbors' trade weighted score. We could not find detailed agricultural trade data for Taiwan (not reported in COMTRADE).

Table 4 presents the protectionism scores by country. The first two columns are unweighted scores with method 1 and method 2 respectively, the next two columns are the tradeweighted protectionism scores, the third set are the same scores but for 2008-11 average trade weights, and the fourth set of two columns shows the neighbors' trade weighted scores, which are trade-weighted scores but using neighbors' trade weight to avoid downward bias in protectionism scores if stringency reduces trade. For simplicity of discussion, we refer the (un)weighted protectionism scores calculated with method 1 and method 2 as (un)weighted score 1 and (un)weighted score 2. The last column in the table shows the sum of non-established MRLs count by country. 12 countries have non-zero count of non-established MRLs. The number of non-established MRLs ranges from 4883 (China) to 856 (EU).

The indices, by design, put heavier weights on the products with higher imports, which indicate the importance of the related products. Whether protectionism scores for large importers should be adjusted downwards is an open question. The MRLs could also be endogenous and may have appeared after an import surge (Trefler (1993)). We believe that different measures presented in table 4 offer complementary insights into the protectionist question. On the one hand, one could argue these large importers are not protecting their domestic industries - trade is sizeable-- even though their standards exceed international norms. Instead, the stringency could be intended to 
protect their consumers with higher health standards and actually increase import demand. The political analysis of Kono (2006) states that politician in more democratic societies tend to be more sensitive to public safety, health and environment. Producers and consumers may demand higher standards.

On the other hand, higher imports may indicate higher demand, but strict MRLs pose a hurdle for other countries with laxer MRL standards. Therefore, their imports come from both countries with equal or stricter MRLs or other non-protectionist countries that incurred extra cost to meet stricter standards. For those lower-standard countries, where MRLs are based on internationally accepted standards or even lower, the strict MRLs of large importers could represent protectionism.

Table 4: Country-level Protectionism Scores $^{7}$

\begin{tabular}{|c|c|c|c|c|c|c|c|c|c|}
\hline \multirow[t]{2}{*}{ Country } & \multicolumn{2}{|c|}{$\begin{array}{l}\text { Unweighted } \\
\text { Protectionism } \\
\text { Scores }\end{array}$} & \multicolumn{2}{|c|}{$\begin{array}{c}2009 \text { Trade } \\
\text { weighted } \\
\text { Protectionism } \\
\text { Scores }\end{array}$} & \multicolumn{2}{|c|}{$\begin{array}{c}\text { 2008-2011 Avg. } \\
\text { Trade Weighted } \\
\text { Protectionism } \\
\text { Scores } \\
\end{array}$} & \multicolumn{2}{|c|}{$\begin{array}{l}\text { Neighbor Trade } \\
\text { weighted } \\
\text { Protectionism } \\
\text { Scores* } \\
\end{array}$} & \multirow[t]{2}{*}{$\begin{array}{c}\text { Count } \\
\text { non- } \\
\text { establis } \\
\text { hed } \\
\text { MRLs }\end{array}$} \\
\hline & Method1 & Method2 & Method1 & Method2 & Method1 & Method2 & Method1 & Method2 & \\
\hline Taiwan & $\begin{array}{c}2.11 \\
(0.47)\end{array}$ & $\begin{array}{c}1.59 \\
(0.61)\end{array}$ & N/A** & N/A & N/A & N/A & $\begin{array}{c}1.89 \\
(0.04)\end{array}$ & $\begin{array}{c}1.34 \\
(0.05)\end{array}$ & 2575 \\
\hline Australia & $\begin{array}{c}1.93 \\
(0.57)^{* * *}\end{array}$ & $\begin{array}{c}1.19 \\
(0.43) \\
\end{array}$ & $\begin{array}{c}1.66 \\
(0.04)\end{array}$ & $\begin{array}{c}1.20 \\
(0.04)\end{array}$ & $\begin{array}{c}1.67 \\
(0.04)\end{array}$ & $\begin{array}{c}1.20 \\
(0.04)\end{array}$ & $\begin{array}{c}1.73 \\
(0.05) \\
\end{array}$ & $\begin{array}{c}1.20 \\
(0.02)\end{array}$ & 2219 \\
\hline Japan & $\begin{array}{c}1.68 \\
(0.76) \\
\end{array}$ & $\begin{array}{c}0.93 \\
(0.26) \\
\end{array}$ & $\begin{array}{c}1.48 \\
(0.06) \\
\end{array}$ & $\begin{array}{c}1.08 \\
(0.03) \\
\end{array}$ & $\begin{array}{c}1.48 \\
(0.06) \\
\end{array}$ & $\begin{array}{c}1.07 \\
(0.02)\end{array}$ & $\begin{array}{c}1.16 \\
(0.05) \\
\end{array}$ & $\begin{array}{c}0.99 \\
(0.02)\end{array}$ & 1580 \\
\hline Jamaica & $\begin{array}{c}1.51 \\
(0.57)\end{array}$ & $\begin{array}{c}1.27 \\
(0.38) \\
\end{array}$ & $\begin{array}{c}1.22 \\
(0.03)\end{array}$ & $\begin{array}{c}1.12 \\
(0.02)\end{array}$ & $\begin{array}{c}1.22 \\
(0.03)\end{array}$ & $\begin{array}{c}1.13 \\
(0.02) \\
\end{array}$ & $\begin{array}{c}1.24 \\
(0.03) \\
\end{array}$ & $\begin{array}{c}1.16 \\
(0.02)\end{array}$ & 856 \\
\hline \begin{tabular}{|l|} 
European \\
Union \\
\end{tabular} & $\begin{array}{c}1.51 \\
(0.57)\end{array}$ & $\begin{array}{c}1.27 \\
(0.38)\end{array}$ & $\begin{array}{c}1.22 \\
(0.04)\end{array}$ & $\begin{array}{c}1.10 \\
(0.02)\end{array}$ & $\begin{array}{c}1.22 \\
(0.04)\end{array}$ & $\begin{array}{c}1.11 \\
(0.02)\end{array}$ & $\begin{array}{c}1.32 \\
(0.03)\end{array}$ & $\begin{array}{c}1.22 \\
(0.02)\end{array}$ & 856 \\
\hline Turkey & $\begin{array}{c}1.48 \\
(0.55)\end{array}$ & $\begin{array}{c}1.23 \\
(0.65)\end{array}$ & $\begin{array}{c}1.21 \\
(0.03)\end{array}$ & $\begin{array}{c}1.50 \\
(0.08)\end{array}$ & $\begin{array}{c}1.24 \\
(0.02)\end{array}$ & $\begin{array}{c}1.43 \\
(0.07)\end{array}$ & $\begin{array}{c}1.22 \\
(0.03)\end{array}$ & $\begin{array}{c}1.39 \\
(0.05) \\
\end{array}$ & 4499 \\
\hline Canada & $\begin{array}{l}1.45 \\
(0.49)\end{array}$ & $\begin{array}{c}1.20 \\
(0.42)\end{array}$ & $\begin{array}{c}1.29 \\
(0.03)\end{array}$ & $\begin{array}{c}1.09 \\
(0.02)\end{array}$ & $\begin{array}{c}1.28 \\
(0.03)\end{array}$ & $\begin{array}{c}1.08 \\
(0.02)\end{array}$ & $\begin{array}{c}1.27 \\
(0.02)\end{array}$ & $\begin{array}{c}1.10 \\
(0.02)\end{array}$ & 2751 \\
\hline Israel & $\begin{array}{c}1.06 \\
(0.21)\end{array}$ & $\begin{array}{c}1.06 \\
(0.21)\end{array}$ & $\begin{array}{c}1.07 \\
(0.01)\end{array}$ & $\begin{array}{c}1.07 \\
(0.01)\end{array}$ & $\begin{array}{c}1.06 \\
(0.01)\end{array}$ & $\begin{array}{c}1.06 \\
(0.01)\end{array}$ & $\begin{array}{c}1.07 \\
(0.01)\end{array}$ & $\begin{array}{c}1.07 \\
(0.01)\end{array}$ & 0 \\
\hline Brazil & $\begin{array}{c}1.04 \\
(0.12)\end{array}$ & $\begin{array}{c}1.33 \\
(0.55)\end{array}$ & $\begin{array}{c}1.11 \\
(0.01)\end{array}$ & $\begin{array}{c}1.26 \\
(0.04)\end{array}$ & $\begin{array}{c}1.11 \\
(0.01)\end{array}$ & $\begin{array}{c}1.25 \\
(0.03)\end{array}$ & $\begin{array}{c}1.08 \\
(0.01)\end{array}$ & $\begin{array}{c}1.20 \\
(0.03)\end{array}$ & 4342 \\
\hline Argentina & $\begin{array}{c}1.04 \\
(0.11)\end{array}$ & $\begin{array}{c}1.04 \\
(0.11)\end{array}$ & $\begin{array}{c}1.18 \\
(0.02)\end{array}$ & $\begin{array}{c}1.18 \\
(0.02)\end{array}$ & $\begin{array}{c}1.16 \\
(0.01)\end{array}$ & $\begin{array}{c}1.16 \\
(0.01)\end{array}$ & $\begin{array}{c}1.13 \\
(0.01)\end{array}$ & $\begin{array}{c}1.13 \\
(0.01)\end{array}$ & 0 \\
\hline Chile & 1.03 & 1.02 & 1.04 & 1.05 & 1.04 & 1.04 & 1.00 & 0.96 & 2684 \\
\hline
\end{tabular}

${ }^{7}$ Countries not listed have protectionism scores equal to one. All figures are rounded to the second digit after the decimal point. 


\begin{tabular}{|c|c|c|c|c|c|c|c|c|c|}
\hline & $(0.14)$ & $(0.30)$ & $(0.01)$ & $(0.01)$ & $(0.01)$ & $(0.01)$ & $(0.01)$ & $(0.01)$ & \\
\hline \begin{tabular}{|l|} 
Russian \\
Federation
\end{tabular} & $\begin{array}{c}1.03 \\
(0.10)\end{array}$ & $\begin{array}{c}1.54 \\
(0.74)\end{array}$ & $\begin{array}{c}1.07 \\
(0.01)\end{array}$ & $\begin{array}{c}1.80 \\
(0.10)\end{array}$ & $\begin{array}{c}1.07 \\
(0.01)\end{array}$ & $\begin{array}{c}1.79 \\
(0.10)\end{array}$ & $\begin{array}{c}1.04 \\
(0.01)\end{array}$ & $\begin{array}{c}1.37 \\
(0.07)\end{array}$ & 4744 \\
\hline \begin{tabular}{|l|} 
Rep. of \\
Korea
\end{tabular} & $\begin{array}{c}1.01 \\
(0.15) \\
\end{array}$ & $\begin{array}{c}0.97 \\
(0.45) \\
\end{array}$ & $\begin{array}{c}0.99 \\
(0.01)\end{array}$ & $\begin{array}{c}0.98 \\
(0.02)\end{array}$ & $\begin{array}{c}0.99 \\
(0.01)\end{array}$ & $\begin{array}{c}0.98 \\
(0.02)\end{array}$ & $\begin{array}{c}0.98 \\
(0.01) \\
\end{array}$ & $\begin{array}{c}0.92 \\
(0.02) \\
\end{array}$ & 3867 \\
\hline China & $\begin{array}{c}1.01 \\
(0.05)\end{array}$ & $\begin{array}{c}1.04 \\
(0.38)\end{array}$ & $\begin{array}{c}1.00 \\
(0.00)\end{array}$ & $\begin{array}{c}0.99 \\
(0.03)\end{array}$ & $\begin{array}{c}1.00 \\
(0.00)\end{array}$ & $\begin{array}{c}0.99 \\
(0.03)\end{array}$ & $\begin{array}{c}1.01 \\
(0.00) \\
\end{array}$ & $\begin{array}{c}1.05 \\
(0.03) \\
\end{array}$ & 4883 \\
\hline Malaysia & $\begin{array}{c}0.99 \\
(0.04)\end{array}$ & $\begin{array}{c}0.99 \\
(0.04)\end{array}$ & $\begin{array}{c}0.99 \\
(0.00)\end{array}$ & $\begin{array}{c}0.99 \\
(0.00)\end{array}$ & $\begin{array}{c}0.99 \\
(0.00)\end{array}$ & $\begin{array}{c}0.99 \\
(0.00)\end{array}$ & $\begin{array}{c}1.00 \\
(0.00)\end{array}$ & $\begin{array}{c}1.00 \\
(0.00)\end{array}$ & 0 \\
\hline $\begin{array}{l}\text { Unit. Arab } \\
\text { Emirates }\end{array}$ & $\begin{array}{c}0.99 \\
(0.03)\end{array}$ & $\begin{array}{c}0.99 \\
(0.03)\end{array}$ & $\begin{array}{c}0.99 \\
(0.01)\end{array}$ & $\begin{array}{c}0.99 \\
(0.01)\end{array}$ & $\begin{array}{c}0.99 \\
(0.00)\end{array}$ & $\begin{array}{c}0.99 \\
(0.00)\end{array}$ & $\begin{array}{c}0.99 \\
(0.00)\end{array}$ & $\begin{array}{c}0.99 \\
(0.00)\end{array}$ & 0 \\
\hline Mexico & $\begin{array}{c}0.99 \\
(0.36)\end{array}$ & $\begin{array}{c}0.99 \\
(0.36)\end{array}$ & $\begin{array}{c}0.98 \\
(0.02)\end{array}$ & $\begin{array}{c}0.98 \\
(0.02)\end{array}$ & $\begin{array}{c}0.98 \\
(0.02)\end{array}$ & $\begin{array}{c}0.98 \\
(0.02)\end{array}$ & $\begin{array}{c}0.92 \\
(0.02)\end{array}$ & $\begin{array}{c}0.92 \\
(0.02)\end{array}$ & 0 \\
\hline \begin{tabular}{|l} 
United \\
States
\end{tabular} & $\begin{array}{c}0.98 \\
(0.36)\end{array}$ & $\begin{array}{c}0.98 \\
(0.36)\end{array}$ & $\begin{array}{c}0.89 \\
(0.02)\end{array}$ & $\begin{array}{c}0.89 \\
(0.02)\end{array}$ & $\begin{array}{c}0.90 \\
(0.02)\end{array}$ & $\begin{array}{c}0.90 \\
(0.02)\end{array}$ & $\begin{array}{c}0.93 \\
(0.01)\end{array}$ & $\begin{array}{c}0.93 \\
(0.01)\end{array}$ & 0 \\
\hline India & $\begin{array}{c}0.98 \\
(0.13) \\
\end{array}$ & $\begin{array}{c}0.97 \\
(0.18) \\
\end{array}$ & $\begin{array}{c}1.03 \\
(0.01)\end{array}$ & $\begin{array}{c}1.04 \\
(0.01)\end{array}$ & $\begin{array}{c}1.03 \\
(0.01) \\
\end{array}$ & $\begin{array}{c}1.05 \\
(0.01) \\
\end{array}$ & $\begin{array}{c}1.03 \\
(0.01) \\
\end{array}$ & $\begin{array}{c}1.06 \\
(0.01) \\
\end{array}$ & 1859 \\
\hline \begin{tabular}{|l|} 
New \\
Zealand \\
\end{tabular} & $\begin{array}{c}0.97 \\
(0.06)\end{array}$ & $\begin{array}{c}0.97 \\
(0.06) \\
\end{array}$ & $\begin{array}{c}0.97 \\
(0.00) \\
\end{array}$ & $\begin{array}{c}0.97 \\
(0.00)\end{array}$ & $\begin{array}{c}0.97 \\
(0.00) \\
\end{array}$ & $\begin{array}{c}0.97 \\
(0.00)\end{array}$ & $\begin{array}{c}0.98 \\
(0.00) \\
\end{array}$ & $\begin{array}{c}0.98 \\
(0.00) \\
\end{array}$ & 0 \\
\hline Singapore & $\begin{array}{c}0.96 \\
(0.13)\end{array}$ & $\begin{array}{c}0.96 \\
(0.13)\end{array}$ & $\begin{array}{c}0.98 \\
(0.01)\end{array}$ & $\begin{array}{c}0.98 \\
(0.01)\end{array}$ & $\begin{array}{c}0.98 \\
(0.01)\end{array}$ & $\begin{array}{c}0.98 \\
(0.01)\end{array}$ & $\begin{array}{c}0.98 \\
(0.00)\end{array}$ & $\begin{array}{c}0.98 \\
(0.00)\end{array}$ & 0 \\
\hline \begin{tabular}{|l|} 
South \\
Africa \\
\end{tabular} & $\begin{array}{c}0.87 \\
(0.14)\end{array}$ & $\begin{array}{c}0.87 \\
(0.14)\end{array}$ & $\begin{array}{c}0.82 \\
(0.01)\end{array}$ & $\begin{array}{c}0.82 \\
(0.01)\end{array}$ & $\begin{array}{c}0.81 \\
(0.01)\end{array}$ & $\begin{array}{c}0.81 \\
(0.01)\end{array}$ & $\begin{array}{c}0.84 \\
(0.00)\end{array}$ & $\begin{array}{c}0.84 \\
(0.00)\end{array}$ & 0 \\
\hline Sri Lanka & $\begin{array}{c}0.52 \\
(0.20)\end{array}$ & $\begin{array}{c}0.54 \\
(0.19)\end{array}$ & $\begin{array}{c}0.43 \\
(0.01)\end{array}$ & $\begin{array}{c}0.47 \\
(0.01)\end{array}$ & $\begin{array}{c}0.42 \\
(0.01)\end{array}$ & $\begin{array}{c}0.47 \\
(0.01)\end{array}$ & $\begin{array}{c}0.45 \\
(0.01) \\
\end{array}$ & $\begin{array}{c}0.48 \\
(0.01)\end{array}$ & 0 \\
\hline Albania & $\begin{array}{c}0.52 \\
(0.20)\end{array}$ & $\begin{array}{c}0.54 \\
(0.19)\end{array}$ & $\begin{array}{c}0.46 \\
(0.01)\end{array}$ & $\begin{array}{c}0.50 \\
(0.01)\end{array}$ & $\begin{array}{c}0.46 \\
(0.01)\end{array}$ & $\begin{array}{c}0.51 \\
(0.01)\end{array}$ & $\begin{array}{c}0.43 \\
(0.01)\end{array}$ & $\begin{array}{c}0.45 \\
(0.01)\end{array}$ & 0 \\
\hline $\begin{array}{l}\text { Antigua } \\
\text { and } \\
\text { Barbuda }\end{array}$ & $\begin{array}{c}0.52 \\
(0.20)\end{array}$ & $\begin{array}{c}0.54 \\
(0.19)\end{array}$ & $\begin{array}{c}0.39 \\
(0.01)\end{array}$ & $\begin{array}{c}0.46 \\
(0.01)\end{array}$ & $\begin{array}{c}0.39 \\
(0.01)\end{array}$ & $\begin{array}{c}0.46 \\
(0.01)\end{array}$ & $\begin{array}{c}0.50 \\
(0.01)\end{array}$ & $\begin{array}{c}0.54 \\
(0.01)\end{array}$ & 0 \\
\hline \begin{tabular}{|l|} 
Cayman \\
Islands
\end{tabular} & $\begin{array}{c}0.52 \\
(0.20)\end{array}$ & $\begin{array}{c}0.54 \\
(0.19)\end{array}$ & N/A** & N/A & N/A & N/A & $\begin{array}{c}0.51 \\
(0.01)\end{array}$ & $\begin{array}{c}0.55 \\
(0.01)\end{array}$ & 0 \\
\hline Haiti & $\begin{array}{c}0.52 \\
(0.20)\end{array}$ & $\begin{array}{c}0.54 \\
(0.19)\end{array}$ & N/A** & N/A & N/A & N/A & $\begin{array}{c}0.54 \\
(0.01)\end{array}$ & $\begin{array}{c}0.57 \\
(0.01)\end{array}$ & 0 \\
\hline $\begin{array}{l}\text { Saint Kitts } \\
\text { and Nevis }\end{array}$ & $\begin{array}{c}0.52 \\
(0.20) \\
\end{array}$ & $\begin{array}{c}0.54 \\
(0.19)\end{array}$ & $\begin{array}{c}0.39 \\
(0.01)\end{array}$ & $\begin{array}{c}0.46 \\
(0.01)\end{array}$ & $\begin{array}{c}0.39 \\
(0.01)\end{array}$ & $\begin{array}{c}0.46 \\
(0.01)\end{array}$ & $\begin{array}{c}0.50 \\
(0.01)\end{array}$ & $\begin{array}{c}0.55 \\
(0.01)\end{array}$ & 0 \\
\hline Saint Lucia & $\begin{array}{c}0.52 \\
(0.20)\end{array}$ & $\begin{array}{c}0.54 \\
(0.19)\end{array}$ & N/A & N/A & $\begin{array}{c}0.40 \\
(0.01)\end{array}$ & $\begin{array}{c}0.47 \\
(0.01)\end{array}$ & $\begin{array}{c}0.50 \\
(0.01)\end{array}$ & $\begin{array}{c}0.55 \\
(0.01)\end{array}$ & 0 \\
\hline
\end{tabular}

*Note: Neighboring weights are import trade weights based on bordering country data from CEPII and from the 5 closest neighboring countries for countries with no bordering states. Trade data come from COMTRADE, and these data are of the average of 2008-2011.**Taiwanese, Cayman Island, and Haiti detailed trade flows are not available in COMTRADE; Saint Lucia 2009 trade flow data are not available in COMTRADE.

***Note: Numbers within parentheses are standard deviations of the (country $\times$ product) level protectionism scores.

The variation of scores for a given country comes from two sources: the difference between method 1 and method 2; and the weights and normalization method. The difference between scores 1 and 2 (under similar weights) depends on the number of non-established MRLs and 
differences between the default MRL level and the other established MRLs for that country. A much larger score 1 than score 2 indicates a default MRL being relatively stricter than established MRLs and indicates that protectionism in that country is caused by a protectionist default rather than by a concerted effort to be stringent on a particular MRL. The data could also have some missing MRLs, which are confounded with non-established MRLs. We keep this caveat in mind when drawing implications about discrepancies between scores 1 and 2 .

We also note some differences between trade-weighted and equally-weighted scores for a given country; the trade-weighted score could be higher or lower than or close to the equally-weighted score. Self-evidently, if a country has higher trade-weighted scores relative to equally-weighted scores, products with strict MRLs are heavily imported. Conversely, if a country has lower tradeweighted scores than equally-weighted scores, products with less stringent MRLs are heavily imported.

Taiwan, Australia, Japan, the EU, Jamaica, Turkey, and Canada rank among protectionist MRL regimes based on score1 both weighted and unweighted (neighbor-weighted only for Taiwan). Taiwan, Australia, and Japan have substantial difference between score 1 and score 2, because of their large number of non-established MRLs and their tight default levels leading to their score 1 being larger than their score 2. Much of the protectionism in MRLs in these three countries arises from the tight default. Australia, Taiwan, the EU, and Canada also exhibit some protection in established MRLs. Again here the caveat applies on potentially missing data and the potential upward bias in score 1. The EU, Canada, and Jamaica have similar but more moderate patterns because of their smaller number of non-established MRLs which limits the magnitude of the difference between scores 1 and 2 .

Chile, Korea, and India, despite their large number of non-established MRLs, have close score 1 and score 2. The default MRL level of these countries (Codex) is similar to their established 
MRLs. Since score 1 and score 2 are close, we feel confident to conclude that these countries do not exhibit MRL protectionism. The United States is not protectionist based on any of the unweighted/weighted scores 1 and scores 2, and even shows evidence of slight "antiprotectionism" (below Codex) based on trade-weighted scores. South Africa, Albania, Antigua and Barbuda, Cayman Islands, Haiti, Saint Kitts and Nevis, and Sri Lanka have score 1 and score 2 well below one, indicating they might be under protecting their consumers. Sri Lanka's weak regulatory environment for pesticides and its consequences for public health have been noted in the literature (Roberts et al., 2003, and Karalliedde et al., 2001). Singapore and New Zealand show scores very close to but slightly under 1 . All other countries follow Codex and have indices equal to 1 .

Also notable, the Russian Federation and Brazil have higher protectionist scores 2 than scores 1, suggesting that their established MRLs is chiefly responsible for their MRL protectionism. Their low default and large number of non-established MRLs make them appear moderately protectionist and mitigates the protectionism of establish MRLs. Turkey illustrates the importance of weights. With trade weights, it appears that protectionism arises more from established MRLs, whereas with unweighted scores, Turkey's protectionism seems to come from both established and default MRLs. For the EU and the US, trade-weighted scores are lower than equally-weighted scores, indicating that some heavily imported products face less stringent standards. For some other countries, we observe trade-weighted scores higher than unweighted scores for one of or both score 1 and score 2. Stringent MRLs exceeding international norms affect heavily traded products, possibly as a reaction to import surges.

Finally, NAFTA integration on residue standards has been much deeper between Mexico and the United States, relative to what Canada has done with its own standards, a surprising finding. Unlike for tariffs, MRL regulations have not been harmonized across the three NAFTA 
members. Each score comes with an estimated standard deviation, reflecting the variation of product scores for each country. For trade-weighted scores' standard deviations, products with smaller import shares count for less and vise-versa. Generally, notable differences between scores 1 and 2 for any country, extend to their standard deviations. A significantly higher score (either 1 or 2 ) for a country tends to show higher standard deviation for the corresponding score. Hence, we do not see evidence of countries being non-protectionist "on average" by offsetting protectionist MRLs with anti-protectionist ones. In most cases, standard deviations are small relative to scores suggesting the scores and indices are informative.

Country scores based on neighboring-country trade weights provide similar qualitative patterns as the own-country trade weighted scores. We use the CEPII distance database to determine bordering countries and use the 5 shortest-distance countries for countries without bordering neighbors. (Details are available from the authors). The objective is detect biases if trade impediments result from stringent MRLs and lead to underreporting the trade impeding effect of MRL regulation in the country of interest. These score are shown in the last 2 columns of table 4. The patterns with neighbors' weight look qualitatively similar to those obtained with own country trade weights. The only notable difference is for Japan for which the own trade weight score 1 is 1.48 whereas it falls to 1.18 using neighbors' trade weights. For other countries the differences are small in absolute value.

\section{Product level results}

We turn to product scores next. We average them over all countries and regulated substances by product. Detailed scores are available upon request. The averaging over all countries leads to smaller variations. The maximum of equally-weighted scores 1 is 1.28 (Green onion) and minimum is 0.75 (Guava). The maximum of equally-weighted score 2 is 1.21 (Belgian endive) and minimum is 0.74 (Guava). Adding trade weights expands the variation of the scores. The 
maximum of trade-weighted score 1 is 2.47 (Belgian endive) and minimum is 0.42 (Guava); the maximum of trade-weighted scores 2 is 2.10 (Belgian endive) and minimum is 0.19 (Plantain). Lower scores for tropical products is a recurrent theme in product scores.

We further computed product scores for high-income and low-income countries groupings. We use the WDI classification to pigeon-hole countries into the two groups. We see that on average high-income countries have higher product scores than low-income countries do. For example, unweighted scores 1 , on average are almost $13 \%$ larger for high-income countries than they are for low-income countries. This occurs with some geographic variation. For tropical fruits (passion fruit, mango, guava, etc), low-income countries tend actually to have higher product scores than high-income countries do, which is consistent with either export quality objectives by these low-income countries or protection of local markets and consumers. In contrast for temperate products like turnips, high-income countries tend to have much higher product scores potentially for similar reasons. In addition, scores 1 on average, show larger differences (in percent deviation) between high and low income scores, than scores 2 do. So it appears that non-established MRLs tend o exacerbate the "high-low income "difference" on product scores. Trade weights also exacerbate the higher scores in high income countries relative to low income countries.

To better elucidate the product-level protectionism, we look at score distribution plots by grouping products by HS2 digit sectors, and then select a few commonly-discussed products to investigate their MRL protectionism. Table 5 shows HS2 digit sectors, associated products that fall into each sector, the number of products in each sector, and the number of non-established MRLs for the product. The boxplots of weighted protectionism scores and unweighted scores for each sector are presented in figures 1 and 2. The Score1 plot shows a wider dispersion and higher mean than score 2 for fruit and vegetables. This observation shows that substituting non- 
established MRLs with default levels risks inflating these products’ protectionism scores. Animal products (HS02 and HS15) seem to have little discrepancy between score 1 and score 2 .

Table 5: Products categorized in HS 2-digit sectors

\begin{tabular}{|l|c|l|l|}
\hline HS 2-digit sector descriptions & $\begin{array}{l}\text { Number } \\
\text { of } \\
\text { products }\end{array}$ & $\begin{array}{l}\text { Count of non- } \\
\text { established } \\
\text { MRLs }\end{array}$ & Details of products \\
\hline $\begin{array}{l}\text { 02: MEAT \& EDIBLE MEAT } \\
\text { OFFAL }\end{array}$ & 18 & 11,505 & $\begin{array}{l}\text { cattle by-products, cattle meat, cattle } \\
\text { liver, etc. }\end{array}$ \\
\hline $\begin{array}{l}\text { 04: DAIRY, EGGS, HONEY, \& } \\
\text { ED. PRODUCTS }\end{array}$ & 3 & 1,879 & egg, milk, milk fat \\
\hline $\begin{array}{l}\text { 06: LIVE TREES } \\
\text { \& OTHER PLANTS }\end{array}$ & 4 & 355 & $\begin{array}{l}\text { chicory roots, chufa, dasheen corm, } \\
\text { canna edible }\end{array}$ \\
\hline $\begin{array}{l}\text { 07: EDIBLE VEGETABLES } \\
\text { 08: ED. FRUITS \& NUTS, PEEL } \\
\text { OF CITRUS/MELONS }\end{array}$ & 73 & 20,229 & $\begin{array}{l}\text { bean, cabbage, pea, spinach, turnip, } \\
\text { tomato, etc. }\end{array}$ \\
\hline $\begin{array}{l}\text { 09: COFFEE, TEA, MATE } \\
\text { \& SPICES }\end{array}$ & 3 & 17,899 & $\begin{array}{l}\text { apple, almond, banana, cherry, lemon, } \\
\text { strawberry, etc }\end{array}$ \\
\hline $\begin{array}{l}\text { 10: CEREALS } \\
\text { 12: OIL SEEDS/MISC. }\end{array}$ & 8 & 1,450 & ginger, pepper, savory summer \\
\hline $\begin{array}{l}\text { GRAINS/MED.PLANTS/STRAW } \\
\text { 15: ANIMAL OR VEGET. FATS, } \\
\text { OILS \& WAXES }\end{array}$ & $4^{8}$ & 1,575 & $\begin{array}{l}\text { cotton seed, hop dried cones, mustard } \\
\text { seed, peanut, sesame seed, sugar beet }\end{array}$ \\
\hline
\end{tabular}

Figure1: Boxplot of Weighted Protectionsim Scores by HS 2-digit Sectors

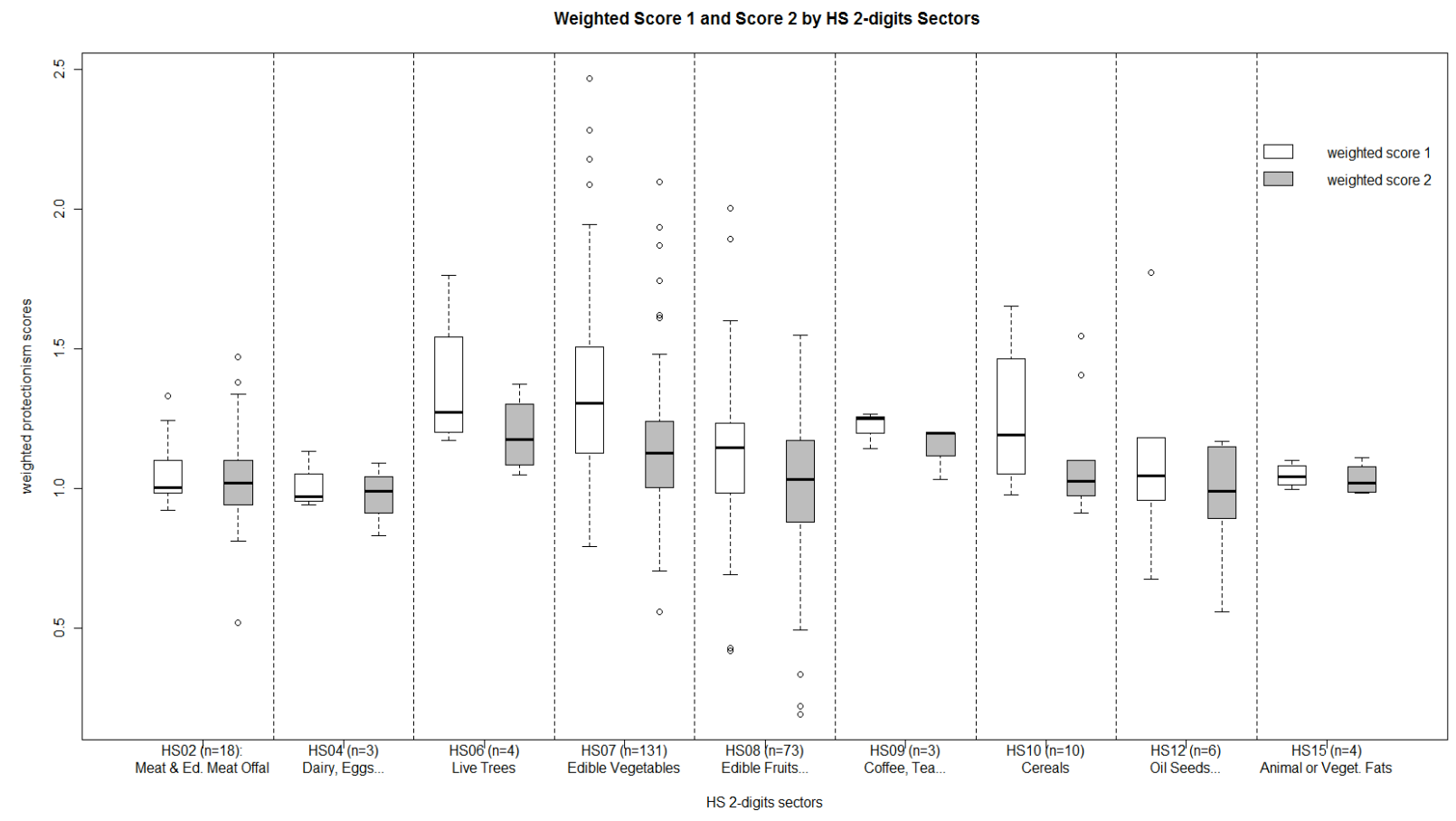

\footnotetext{
${ }^{8}$ Cattle fat and hog fat fall into both HS15 and HS02. We have 254 distinct goods or 277 with redundant products.
} 
Meat, diary, and egg products have the lowest average, and mostly span in the lower protectionism region. This could be due to their relatively high traditional protection via tariffs, tariff rate quotas and farm subsidies in OECD countries. MRL protection may not be necessary. Disdier and van Tongeren (2010) clustered products based on three criteria: the number of notified NTMs, the number of SPS trade concerns officially communicated to the WTO, and the share of imports affected by notified NTMs. They show that meat products and many dairy products fall in the clusters with high NTM trade coverage, high number of notifications, and high/very high number of concerns. However, they did not explicitly measure the strictness of individual policies. Their stylized facts together with our results on product-level protectionism suggest that meat and dairy products are subjected to a high number of NTM notifications but which are relatively less stringent.

Figure2: Boxplot of Unweighted Protectionsim Scores by HS 2-digit Sectors

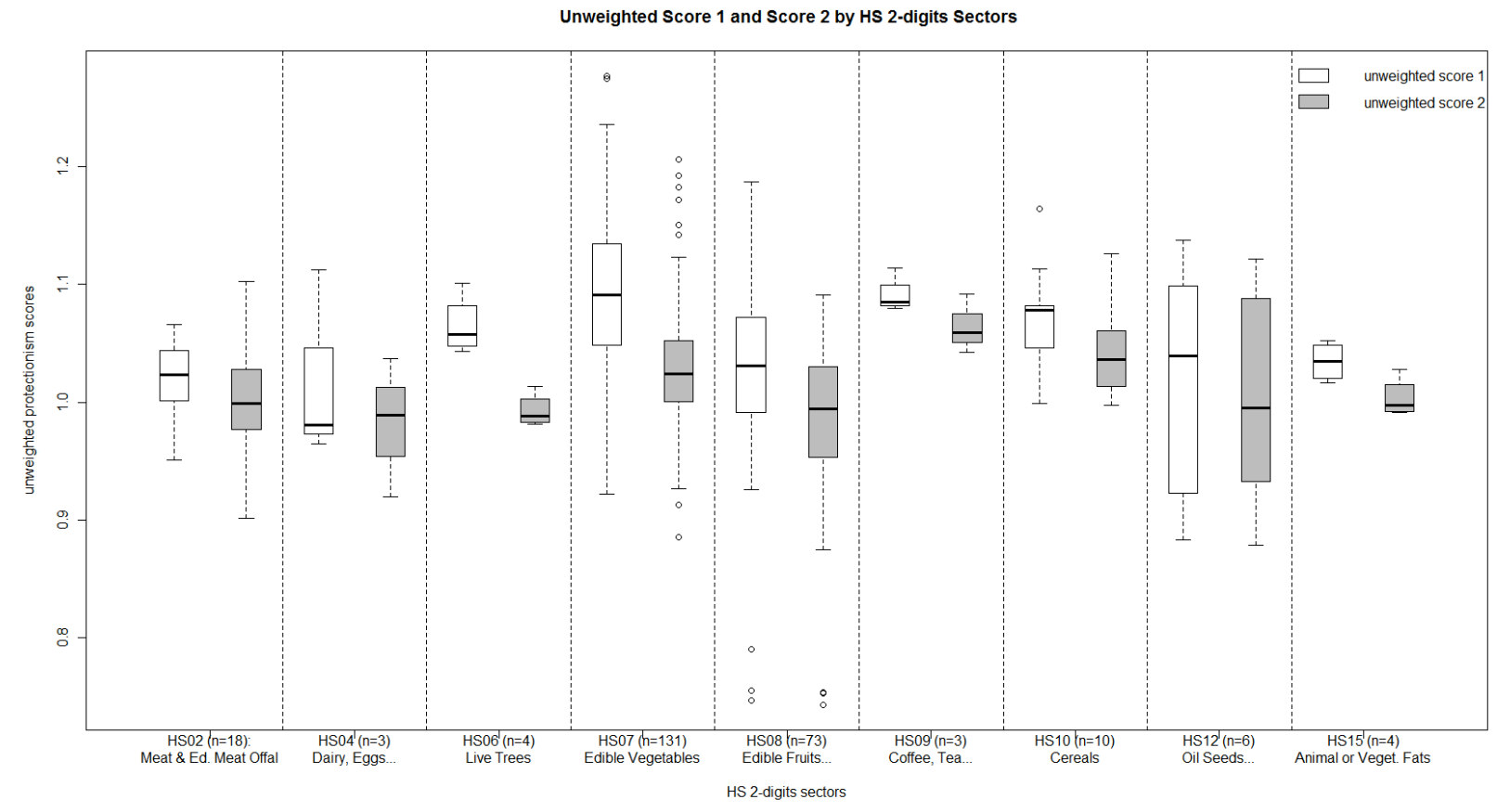

These heavily regulated sectors may not be heavily protected, but rather may involve more health and food safety concerns. Disdier and van Tongeren (2010) also found that vegetable 
products are spread over several clusters with high or low number of notifications. We observe a similar variation in protectionism scores for vegetable products; their protectionism scores have the widest span. The protectionism span is related to the large number of the products in this sector. Fruit product protectionism scores are also found to exhibit large variations. Disdier and van Tongeren (2010) suggest fruit products overall have a high number of notifications and high number of concerns. This again indicates the complexity of gauging protectionism. Frequency of notifications and concerns are not sufficient to establish protectionism; the actual stringency of the standards should also be taken into consideration.

The differences between trade-weighted and equally-weighted scores are quite obvious for product-level scores. Most of the large trade-weighted scores are higher than their equallyweighted scores counterparts, and conversely for low-level scores. A trade-weighted score being higher than its unweighted counterpart means that larger importers tend to have stricter MRLs for that product; and vise versa. More details are available in appendix table 1 . This point is important because it shows that regulatory stringency, even beyond Codex, may actually be associated with large trade flows. Trade may have been facilitated by stringent food regulation. The conventional view of a stringent trade-impeding NTM with a positive ad valorem tariff equivalent is challenged by these occurrences.

The top contributors to unweighted scores are countries that have the tightest MRLs for the corresponding product. Trade weights temper or exacerbate these with import shares. Countries, that contribute large percentage to weighted scores, have large import share and/or large unweighted scores contribution. A weighted commodity score is larger than its unweighted counterpart when countries with stricter MRLs are large or dominant importers (for example, sheep meat, hog meat, grapefruit). The latter is consistent with food safety concerns associated to popular imports. A weighted score is close to or smaller than its unweighted counterpart, when 
there are no dominant importers or when countries with less stringent MRLs are large importers (i.e., banana, poultry meat, wheat, etc.).

A look at the top contributors in scores is interesting (see appendix table 1). For example, the dominant top contributor to weighted score 1 for sheep meat is the EU (43\%), and the EU sheep meat MRLs are among the tightest (one of the top contributors to unweighted scores). Therefore, we see a big increase form unweighted scores to weighted scores. Australia, on the other hand, does not import much sheep meat while keeping tight MRLs. Australia is a large exporter, so it set its MRLs to meet high EU standards where it export lamb product and/or equally to protect its own sheep and lamb markets. The economic and rent-seeking determinants of protectionism scores will be investigated in a subsequent investigation.

\section{Robustness check}

We evaluate the robustness of our scores with a focus on the weights used in the scores (between trade weighted scores and unweighted scores), and also on data limitations and their potential impact on the stability of the protectionism scores. Since we have several products with small substance counts, we find it imperative to check the robustness of the product-level protectionism scores as well as country-level protectionism scores relative to the variation in substance count per product score.

In the dataset, the number of substances for each product ranges from 1 to 98 , and we conjecture that this number is likely to be positively related with the "true" number of substances regulated for this product. One of the possible explanations for the variations could be that some products may raise more health concerns than others. The other potential reason, mentioned before, is that the list is determined by the U.S. list of substances. We have $13 \%$ of the products (34 out of 254) with less or equal to 5 substances (data available upon request). The protectionism scores for products with fewer substances may still be valid, but we certainly have 
more confidence in the scores calculated with more substances. In order to systematically check the robustness, bias, variance as well as identify outliers in the product protectionism scores, we look at box plots of scores grouped by substance count, Quantile-Quantile plots (QQ-plots) with small counts against the rest, and compute some statistical tests, when applicable.

Figure 3 shows the histograms of combinations of weighted and unweighted score 1 and score 2 . The variation shows the patterns for weighted-unweighted, and score 1- score 2 . Trade weight creates more dispersion and higher scores. Figures 4 and 5 show the boxplots of weighted and unweighted protectionism scores grouped by the number of substances. For both weighted and unweighted, products with fewer substances (say substance count $<20$ ) tend to have higher score 1 and a wider dispersion than products with more substances (say substance count $>20$ ). But no obvious difference is found for products with different substance counts for scores 2 , both weighted and unweighted.

QQ plots of product scores (available upon request) are sorted out using cut off numbers of substances. The difference between weighted and unweighted scores is not obvious, but we observe systematic difference between score 1 and score 2 . Score 1 of products with smaller substance count show more variation (fatter left tail) in the lower side and similar variation but higher scores on the upper side, comparing to the same score 1 of products with larger substance count. Scores 2 for products with smaller substance count show more variation (fatter tails) in both lower and upper tails than products with larger substance count. This is consistent with the box plots. Scores with substance count of less or equal to 4 do not line up close to the 45 -degree line but show a much steeper pattern.

In addition to the plots, we conduct non-parametric Cochran tests for the variability and differences among product scores groups. We group products by substance count, i.e., substance count equals $1-4,5-9,9-10$, etc., and try to make each group of similar size of about 30 products. 
Figure 3: Histograms of Protectionism Scores
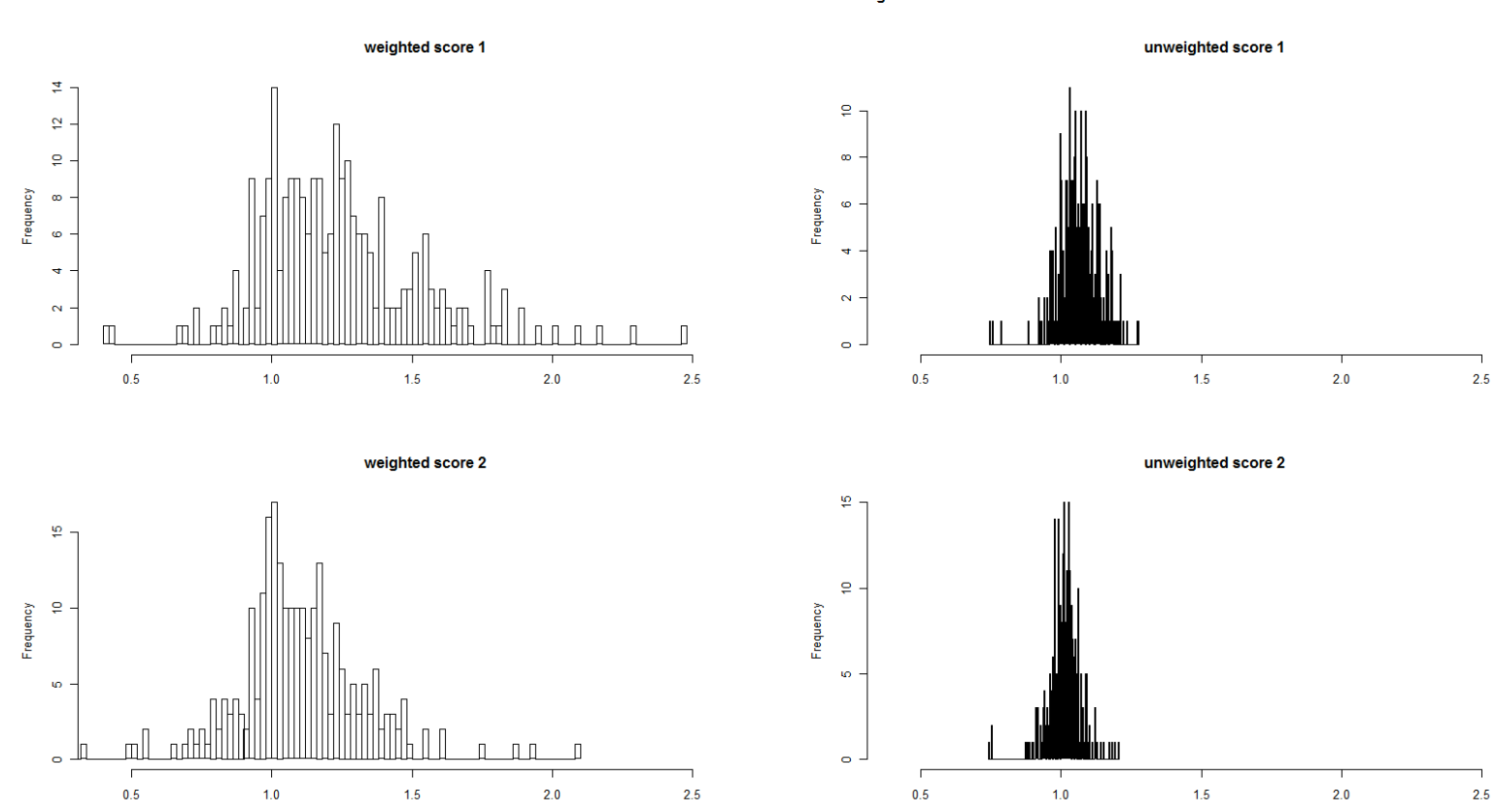

Figure 4: Boxplots of Weighted Scores by Groups of Substance Count

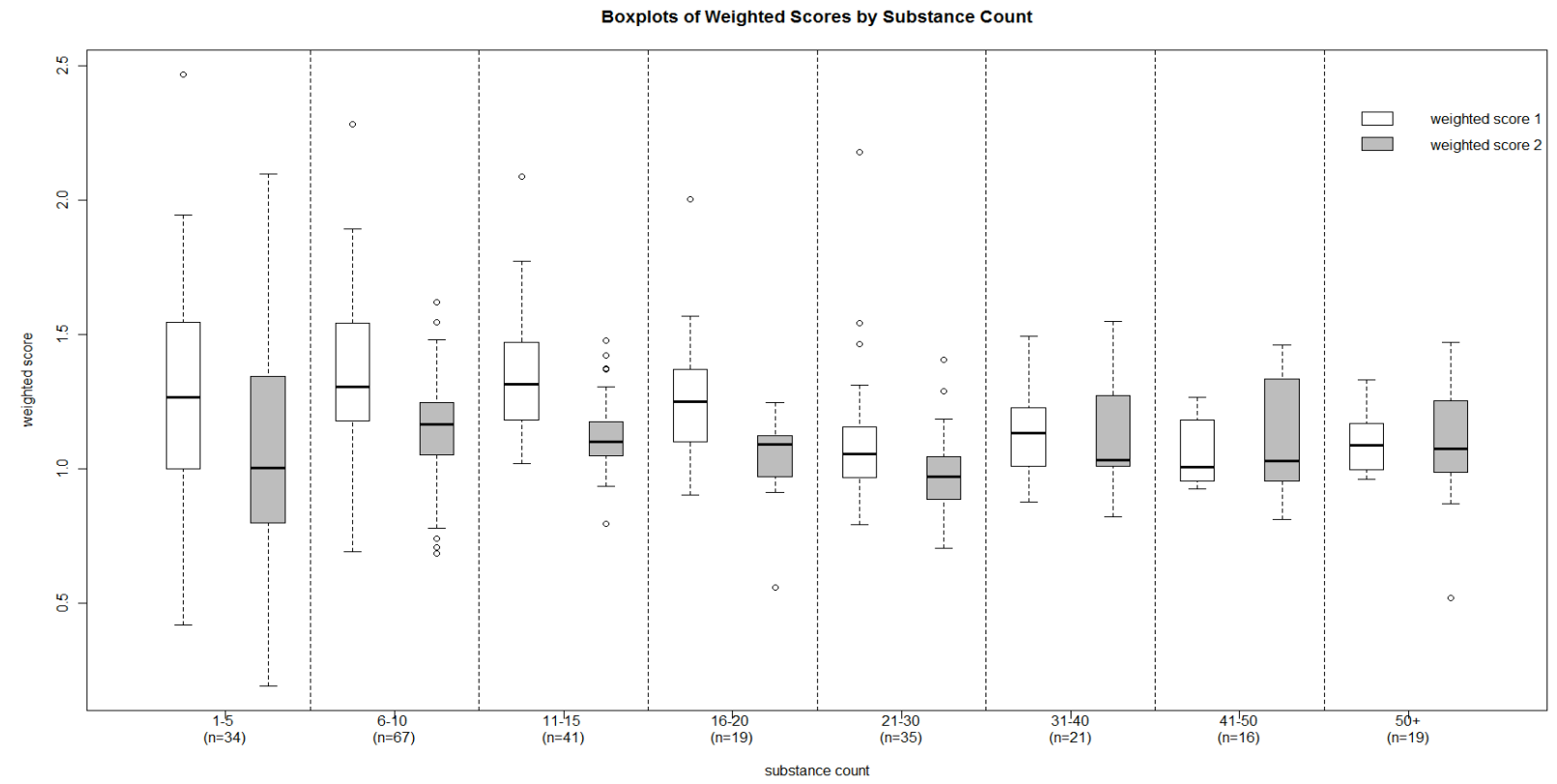

The test suggests that the product group with less or equal to 4 substances have "outlying variance" for all combinations of weighted/unweighted/score $1 /$ score 2 , which means that the scores of products with no more than 4 substances exhibit more variability than the rest. 
However, there is a caveat to the test, which is that it maintains normality, which is rejected for unweighted scores and for some groups of weighted scores.

Figure 5: Boxplots of Unweighted Scores by Groups of Substance Count

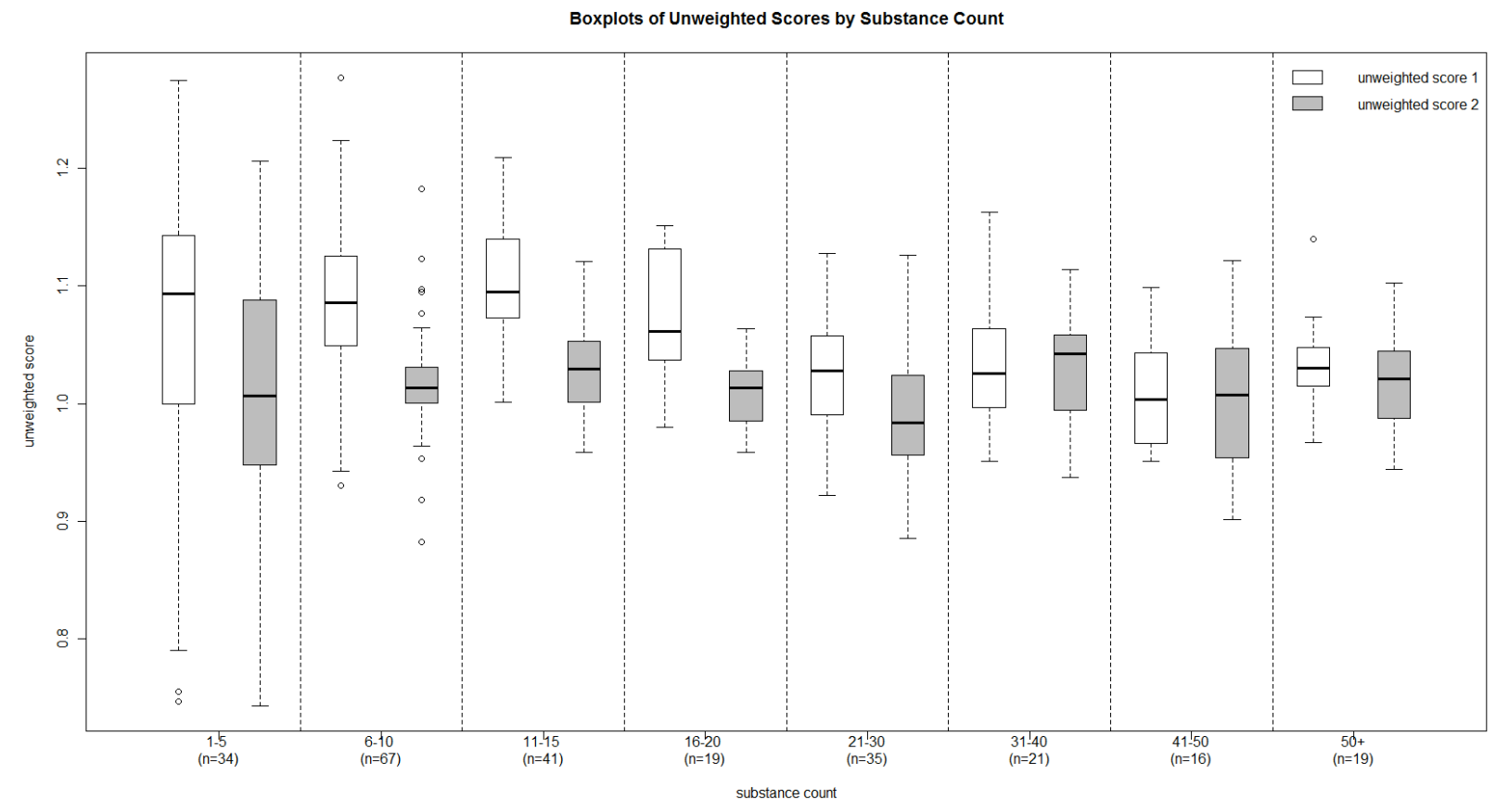

We also check the robustness of country-level scores. We compare the country protectionism scores by gradually deleting products with up to 5 substances, and recalculate them. We see only negligible variations in the scores and country ranking, which strongly suggests that country level scores are robust to the presence of products scores established based on fewer substances (results are available upon request). Finally we check if the incomplete coverage of veterinary drugs affects our country scores. We re-compute the country score by dropping the veterinary drug MRLs. Results are almost unchanged. The average change in a country score is less than $1 \%$. Four countries have a score difference larger than $3 \%$ but smaller than $8 \%$ in absolute value. The ranking of countries is unaffected by abstracting from MRLs on veterinary drugs. So we conclude that this incomplete coverage of veterinary drugs is not an issue. (Results are available from the authors) 


\section{Conclusion}

We proposed well-designed aggregation indices of NTMs to quantify the protectionism of Maximum Residue Limit (MRL) regulations at various level using a science-based criteria embodied in international standards such as Codex Alimentarius. The proposed indices aggregate a similar type of policies and do not suffer from the usual issue of aggregating heterogeneous policy tools into a single index. The latter is difficult to interpret when it is found to affect trade flows. We applied the aggregators to a large international dataset on pesticide and veterinary drug MRLs and associated CODEX MRL standards. We calculated both trade-weighted and equally-weighted scores, since they offer complementary information. Looking at country scores, trade weights do not appear to be pivotal and the bias introduced by trade weights is occasional and small. However, we found trade weights induce more dispersion of product scores. Considering or not non-established MRLs is quite important in establishing a country's MRL protectionism. The latter can arise from strict established MRLs or from strict default MRLs, or both.

Country-level results show that Australia and Taiwan rank the most protectionist from all indices: trade weighted when available, neighbors' trade weighted and equally weighted, using score 1 because of their tight default value. The Russian Federation ranks the most protectionist from scores based on established MRLs (no default). Other countries ranked differently to various extents based on the different weights used. However, the set of most protectionist countries is remarkably stable over the change of weights in indices. We also found that NAFTA integration on residue standards has been much deeper between Mexico and the United States, than with Canada which as set sits MRLs way above Codex and its NAFTA trade partners.

Product level protectionism scores are useful for econometric investigation of disaggregated trade flows and allow to characterize the MRL regulatory regimes for these 
products. Meat and dairy products (HS02, HS04, HS15) have lower protectionism scores in general than other goods. Fruit and vegetable products (HS07, HS08) exhibit the most withinsector variation in protectionism with tropical fruits exhibiting the lowest scores. Breaking down scores by top contributors, we found that products like beans, apple, cattle meat, etc. are controlled by a few dominant importers who set stricter MRLs than other small importers. We checked the robustness of scores to address concerns for products with fewer substances used in their scores. Products with fewer substances seemed consistently biased upward (higher protectionism scores). Some evidence suggests that products scores based on no more than 3 substances have higher variance or noise. As a positive note, country level scores are robust to the deletion of products with fewer substances and provide solid policy implications.

\section{References:}

Achterbosch, T. J., A. Engler, M.-L. Rau and R. Toledo. 2009. "Measure the measure: the impact of differences in pesticide MRLs on Chilean fruit exports to the EU." Paper presented at the International Association of Agricultural Economists Conference, Beijing, China, 16-22.

Baldwin, R.E. 1970. Nontariff Distortions of International Trade. Washington D.C.: Brookings Institution.

Beghin, J.C., A.-C. Disdier, S. Marette, and F. van Tongeren. 2012. "Measuring Costs and Benefits of Non-Tariff Measures in Agri-Food Trade." World Trade Review 11: 356-375.

Berti, K., and R. Falvey. 2009.’Does Trade Weaken Product Quality Standards?’ Bond University Globalization and Development Centre Working paper 29, Australia.

Burnquist, H. L., M. J. P. de, Souza, R. N. de Faria, Rau, M.-L., and K. Shutes. "A Systematic Approach to Regulatory Heterogeneity Applied to EU Agri-Food Trade". NTM-Impact Working Paper.

Carrère, C., \&, J. de Melo (2011). Non-Tariff Measures: What Do We Know, What Might Be Done?. Journal of Economic Integration, 26(1), 169-196.

Disdier, A.-C., and F. van Tongeren. 2010. "Non-Tariff Measures in Agri-Food Trade: What Do the Data Tell Us? Evidence from a Cluster Analysis on OECD Imports." Applied Economic Perspectives and Policy vol. 32(3): 436-455.

Disdier, A.-C., L. Fontagné, and M. Mimouni. 2008. "The Impact of Regulations on Agricultural Trade: Evidence from the SPS and TBT Agreements," American Journal of Agricultural Economics, American Agricultural Economics Association, vol. 90(2), pages 336-350, 05.

Disdier A.-C., and S. Marette. 2010. "The Combination of Gravity and Welfare Approaches for Evaluating Non-Tariff Measures." American Journal of Agricultural Economics, 2010, 92(3): 713-726.

Drogué, S., and F. DeMaria. 2012. Pesticide residues and trade, the apple of discord?. Food 
Policy, 37(6), 641-649.

Fischer, R. and P. Serra. 2000. "Standards and protection," Journal of International Economics vol. 52(2): 377-400.

Fontagné, L., M. Mimouni, and J.-M. Pasteels. 2005. "Estimating the Impact of Environmental SPS and TBT on International Trade." Integration and Trade Journal, 22: 7-37.

Harrigan, J. 1993 "OECD Imports and Trade Barriers in 1983," Journal of International Economics 34(1-2): 91-111.

Karalliedde, L., M. Eddleston, and V. Murray. "The global picture of organophosphate insecticide poisoning." Organophosphates and health (2001): 432-471.

Kono, D. Y. 2006. "Optimal Obfuscation: Democracy and Trade Policy Transparency." American Political Science Review 100(3): 369-384.

Kox, H., and A. Lejour. 2006. "The Effects of the Services Directive on Intra-EU Trade and FDI." Revue économique, Presses de Sciences-Po, vol. 57(4), pages 747-769.

Li, Y., and J.C. Beghin. 2012. A meta-analysis of estimates of the impact of technical barriers to trade. Journal of Policy Modeling, 34(3): 497-511.

Marette, S. and J. C. Beghin. 2010. "Are Standards Always Protectionist?" Review of International Economics, Wiley Blackwell, vol. 18(1): 179-192.

Martinez, A., J. Mora, and J.E. Signoret. 2009. "The CoRe NTMs Database: A Compilation of Reported Non-Tariff Measures." US ITC, Office of Economics Working Paper 2009-12A.

Rau, M.-L., K. Shutes and S. Schlueter. 2010. "Index of Heterogeneity of Requirements in International Agri-Food Trade.” NTM-Impact Working Paper 10/01.

Roberts, D. and T. Josling. 2010. "Tracking the Implementation of Internationally Agreed Standards in Food and Agricultural Production." International Food and Agricultural Trade Policy Council.

Roberts, D. M., Karunarathna, A., Buckley, N. A., Manuweera, G., Sheriff, M. H., \& Eddleston, M. 2003. Influence of pesticide regulation on acute poisoning deaths in Sri Lanka. Bulletin of the World Health Organization, 81(11), 789-798.

Trefler, D. 1993. "Trade Liberalization and the Theory of Endogenous Protection: An Econometric Study of U.S. Import Policy," Journal of Political Economy 101(1): 138-60.

USDA FAS International MRL database (http://www.mrldatabase.com/).

Vigani, M., R. Raimondi and A. Opler. 2009. "GMO Regulations, International Trade and the Imperialism of Standards.” LICOS Discussion Paper 255/2009.

Wilson, J.S., and Otsuki, T. 2004. "To spray or not to spray: pesticides, banana exports, and food safety," Food Policy 29(2): 131-146.

Winchester, N., M-L, Rau, C. Goetz, B. Larue, T. Otsuki, K. Shutes, C. Wieck, H. L. Burnquist, M. J. Pinto de Souza, and R. Nunes de Faria. 2012. "The Impact of Regulatory Heterogeneity on Agri-food Trade." The World Economy 35 no. 8: 973-993.

WTO. Agreement on the Application of Sanitary and Phytosanitary Measures (SPS Agreement) (http://www.wto.org/english/tratop_e/sps_e/spsagr_e.htm).

WTO. 2012. World Trade Report 2012. Trade and public policies: A closer look at non-tariff measures in the 21st century, Geneva, WTO publications.

Xiong, B., and J.C. Beghin. 2012. "Does European aflatoxin regulation hurt groundnut exporters from Africa?." European Review of Agricultural Economics 39 no. 4: 589-609. 
Appendix Table 1: Top Contributors of Protectionism Scores for Selected Products

\begin{tabular}{|c|c|c|c|c|c|c|}
\hline Product & \multicolumn{2}{|c|}{ Score type and level $^{9}$} & Top 5 contributing countries & $\begin{array}{c}\text { Total } \\
\text { contributi } \\
\text { on }\end{array}$ & $\begin{array}{l}\text { Subs. } \\
\text { Count }\end{array}$ & $\begin{array}{c}\text { Non- } \\
\text { established } \\
\text { MRLs count }\end{array}$ \\
\hline \multirow{4}{*}{ Apple } & $\begin{array}{l}\text { weighted } \\
\text { score } 1\end{array}$ & 1.11 & $\begin{array}{l}\text { EU (32\%), Russia (20\%), Canada (5\%), } \\
\text { Mexico (5\%), US (5\%) }\end{array}$ & $67 \%$ & \multirow{4}{*}{64} & \multirow{4}{*}{580} \\
\hline & $\begin{array}{l}\text { weighted score } \\
2\end{array}$ & 1.17 & $\begin{array}{l}\text { EU }(30 \%), \text { Russia }(26 \%), \text { Mexico }(5 \%), \\
\text { US }(5 \%) \text {, Canada }(4 \%)\end{array}$ & $70 \%$ & & \\
\hline & $\begin{array}{l}\text { unweighted } \\
\text { score } 1\end{array}$ & 1.02 & $\begin{array}{l}\text { Australia (3\%), Turkey (3\%), Argentina } \\
(3 \%) \text {, Brazil }(3 \%) \text {, Israel }(3 \%)\end{array}$ & $15 \%$ & & \\
\hline & $\begin{array}{l}\text { unweighted } \\
\text { score } 2\end{array}$ & 1.03 & $\begin{array}{l}\text { Turkey (4\%), Russia (3\%), Brazil (3\%), } \\
\text { Argentina }(3 \%) \text {, Israel }(3 \%)\end{array}$ & $16 \%$ & & \\
\hline & \begin{tabular}{|c} 
weighted score \\
1
\end{tabular} & 0.88 & $\begin{array}{l}\text { EU }(46 \%), \text { US }(19 \%), \text { Japan }(10 \%), \\
\text { Russia }(8 \%) \text {, Canada }(6 \%)\end{array}$ & $89 \%$ & & \\
\hline Banana & $\begin{array}{l}\text { weighted score } \\
2\end{array}$ & 0.85 & $\begin{array}{l}\text { EU }(48 \%), \text { US }(20 \%), \text { Japan }(11 \%), \\
\text { Canada }(6 \%), \text { Russia }(4 \%)\end{array}$ & $89 \%$ & 21 & 121 \\
\hline & $\begin{array}{l}\text { unweighted } \\
\text { score } 1\end{array}$ & 0.96 & $\begin{array}{l}\text { Canada }(3 \%), \text { Israel }(3 \%) \text {, Brazil }(3 \%), \\
\text { Singapore }(2 \%) \text {, Argentina }(2 \%)\end{array}$ & $13 \%$ & & \\
\hline & $\begin{array}{l}\text { Unweighted } \\
\text { score } 2\end{array}$ & 0.95 & $\begin{array}{l}\text { Canada }(3 \%) \text {, Brazil }(3 \%) \text {, Israel }(3 \%), \\
\text { Singapore }(3 \%) \text {, Argentina }(3 \%)\end{array}$ & $15 \%$ & & \\
\hline & $\begin{array}{c}\text { weighted score } \\
1\end{array}$ & 1.17 & $\begin{array}{l}\text { US }(17 \%), \text { Japan }(15 \%), \text { Russia }(14 \%), \\
\text { EU }(14 \%), \text { Mexico }(7 \%)\end{array}$ & $67 \%$ & & \\
\hline $\mathrm{e} \mathrm{m}$ & $\begin{array}{l}\text { weighted score } \\
2\end{array}$ & 1.38 & $\begin{array}{l}\text { Russia }(27 \%) \text {, US }(14 \%) \text {, Japan }(13 \%), \\
\text { EU }(11 \%) \text {, Mexico }(6 \%)\end{array}$ & $71 \%$ & O & 1152 \\
\hline & $\begin{array}{l}\text { unweighted } \\
\text { score } 1\end{array}$ & 1.05 & $\begin{array}{l}\text { Australia (3\%), Jamaica (3\%), EU (3\%), } \\
\text { Mexico (3\%), Japan (3\%) }\end{array}$ & $15 \%$ & & \\
\hline & $\begin{array}{l}\text { Unweighted } \\
\text { score } 2\end{array}$ & 1.08 & $\begin{array}{l}\text { Russia (5\%), Jamaica (3\%), EU (3\%), } \\
\text { Mexico (3\%), Australia (3\%) }\end{array}$ & $17 \%$ & & \\
\hline & $\begin{array}{l}\text { weighted score } \\
1\end{array}$ & 0.98 & $\begin{array}{l}\text { EU }(21 \%), \text { Malaysia }(19 \%), \text { US }(18 \%), \\
\text { Canada }(7 \%), \text { Russia }(5 \%)\end{array}$ & $70 \%$ & & \\
\hline Corn ora & $\begin{array}{l}\text { weighted score } \\
2\end{array}$ & 0.97 & $\begin{array}{l}\text { Malaysia }(20 \%), \text { EU }(20 \%), \text { US }(18 \%), \\
\text { Canada }(7 \%), \text { Russia }(5 \%)\end{array}$ & $70 \%$ & 42 & 243 \\
\hline & $\begin{array}{l}\text { unweighted } \\
\text { score } 1\end{array}$ & 1 & $\begin{array}{l}\text { Australia }(3 \%) \text {, Israel }(2 \%) \text {, China }(2 \%) \text {, } \\
\text { India }(2 \%) \text {, Turkey }(2 \%)\end{array}$ & $11 \%$ & & \\
\hline & $\begin{array}{l}\text { Unweighted } \\
\text { score } 2\end{array}$ & 1 & $\begin{array}{l}\text { China }(3 \%) \text {, Turkey }(3 \%), \text { Indonesia } \\
(2 \%) \text {, Israel }(2 \%) \text {, India }(2 \%)\end{array}$ & $12 \%$ & & \\
\hline Hog, meat & $\begin{array}{c}\text { weighted score } \\
1\end{array}$ & 1.24 & $\begin{array}{l}\text { Japan }(43 \%) \text {, Russia }(16 \%) \text {, Mexico }(8 \%) \text {, } \\
\text { US }(8 \%) \text {, Korea }(5 \%)\end{array}$ & $80 \%$ & 62 & 403 \\
\hline
\end{tabular}

\footnotetext{
${ }^{9}$ We only present own-trade weighted scores here. Neighbors' trade weighted scores are available upon request.
} 


\begin{tabular}{|c|c|c|c|c|c|c|}
\hline & $\begin{array}{c}\text { weighted score } \\
2\end{array}$ & 1.47 & $\begin{array}{l}\text { Japan (35\%), Russia (30\%), Mexico (7\%), } \\
\text { US }(6 \%) \text {, Korea }(4 \%)\end{array}$ & $82 \%$ & & \\
\hline & $\begin{array}{l}\text { unweighted } \\
\text { score1 }\end{array}$ & 1.07 & $\begin{array}{l}\text { Jamaica }(3 \%) \text {, EU (3\%), Mexico (3\%), } \\
\text { Australia }(3 \%) \text {, Japan }(3 \%)\end{array}$ & $15 \%$ & & \\
\hline & $\begin{array}{l}\text { Unweighted } \\
\text { score } 2\end{array}$ & 1.09 & $\begin{array}{l}\text { Russia (6\%), Jamaica (4\%), Mexico (4\%), } \\
\text { EU (4\%), Canada (3\%) }\end{array}$ & $21 \%$ & & \\
\hline \multirow{4}{*}{ Grapefruit } & \begin{tabular}{|c|} 
weighted score \\
1 \\
\end{tabular} & 1.27 & $\begin{array}{l}\text { EU (63\%), Japan (19\%), Russia (9\%), } \\
\text { Canada (6\%), Hong Kong (1\%) }\end{array}$ & $98 \%$ & \multirow{4}{*}{43} & \multirow{4}{*}{241} \\
\hline & \begin{tabular}{|c|} 
weighted score \\
2
\end{tabular} & 1.32 & $\begin{array}{l}\text { EU }(60 \%) \text {, Japan }(16 \%) \text {, Russia }(16 \%) \text {, } \\
\text { Canada }(4 \%) \text {, Hong Kong }(1 \%)\end{array}$ & $97 \%$ & & \\
\hline & $\begin{array}{l}\text { unweighted } \\
\text { score } 1\end{array}$ & 1.06 & $\begin{array}{l}\text { Australia (4\%), Turkey }(4 \%) \text {, EU (4\%), } \\
\text { Canada (4\%), Argentina (3\%) }\end{array}$ & $19 \%$ & & \\
\hline & $\begin{array}{l}\text { Unweighted } \\
\text { score } 2 \\
\end{array}$ & 1.08 & $\begin{array}{l}\text { Russia (6\%), Turkey (5\%), EU (4\%), } \\
\text { Brazil (3\%), Argentina (3\%) }\end{array}$ & $21 \%$ & & \\
\hline \multirow{4}{*}{$\begin{array}{l}\text { Poultry, } \\
\text { meat }\end{array}$} & \begin{tabular}{|c|} 
weighted score \\
1
\end{tabular} & 0.98 & $\begin{array}{l}\text { Hong Kong }(17 \%) \text {, Russia (16\%), China } \\
(13 \%) \text {, Japan }(13 \%) \text {, Mexico }(9 \%)\end{array}$ & $68 \%$ & \multirow{4}{*}{45} & \multirow{4}{*}{281} \\
\hline & $\begin{array}{c}\text { weighted score } \\
2\end{array}$ & 1.04 & $\begin{array}{l}\text { Russia (21\%), Hong Kong (16\%), China } \\
(12 \%) \text {, Japan }(12 \%) \text {, Mexico (8\%) }\end{array}$ & $69 \%$ & & \\
\hline & $\begin{array}{l}\text { unweighted } \\
\text { score } 1 \\
\end{array}$ & 0.97 & $\begin{array}{l}\text { Russia (2\%), Japan (2\%), EU (2\%), Chile } \\
(2 \%) \text {, Singapore }(2 \%)\end{array}$ & $10 \%$ & & \\
\hline & $\begin{array}{l}\text { Unweighted } \\
\text { score } 2 \\
\end{array}$ & 0.98 & $\begin{array}{l}\text { Russia (3\%), Japan (2\%), Chile (2\%), } \\
\text { Singapore (2\%), Thailand (2\%) }\end{array}$ & $11 \%$ & & \\
\hline \multirow{4}{*}{$\begin{array}{c}\text { Sheep, } \\
\text { meat }\end{array}$} & \begin{tabular}{|c|} 
weighted score \\
1
\end{tabular} & 1.33 & $\begin{array}{l}\text { EU (53\%), US (17\%), United Arab } \\
\text { Emirates (6\%), Japan (4\%), Canada (4\%) }\end{array}$ & $84 \%$ & \multirow{4}{*}{66} & \multirow{4}{*}{487} \\
\hline & \begin{tabular}{|c|} 
weighted score \\
2
\end{tabular} & 1.34 & \begin{tabular}{|l|} 
EU (50\%), US (17\%), United Arab \\
Emirates $(6 \%)$, Canada (5\%), China (5\%)
\end{tabular} & $83 \%$ & & \\
\hline & $\begin{array}{l}\text { unweighted } \\
\text { score } 1\end{array}$ & 1.06 & $\begin{array}{l}\text { Jamaica (3\%), Australia (3\%), EU (3\%), } \\
\text { Japan (3\%), Mexico (3\%) }\end{array}$ & $15 \%$ & & \\
\hline & $\begin{array}{l}\text { Unweighted } \\
\text { score } 2\end{array}$ & 1.1 & $\begin{array}{l}\text { Russia }(6 \%) \text {, Canada (4\%), Jamaica (3\%), } \\
\text { Australia }(3 \%) \text {, EU (3\%) }\end{array}$ & $19 \%$ & & \\
\hline \multirow{4}{*}{$\begin{array}{l}\text { Wheat, } \\
\text { grain }\end{array}$} & $\mid \begin{array}{c}\text { weighted score } \\
1\end{array}$ & 1.05 & $\begin{array}{l}\text { EU (10\%), Algeria (9\%), Egypt (8\%), } \\
\text { Japan (7\%), Indonesia (7\%) }\end{array}$ & $41 \%$ & \multirow{4}{*}{38} & \multirow{4}{*}{200} \\
\hline & \begin{tabular}{|c|} 
weighted score \\
2 \\
\end{tabular} & 1.1 & $\begin{array}{l}\text { Turkey (9\%), EU (9\%), Algeria (9\%), } \\
\text { Egypt (7\%), Indonesia (7\%) }\end{array}$ & $41 \%$ & & \\
\hline & $\begin{array}{l}\text { unweighted } \\
\text { score1 }\end{array}$ & 1.05 & $\begin{array}{l}\text { Australia (3\%), Canada (3\%), Turkey } \\
(3 \%) \text {, India (3\%), China (3\%) }\end{array}$ & $15 \%$ & & \\
\hline & $\begin{array}{l}\text { Unweighted } \\
\text { score2 }\end{array}$ & 1.07 & $\begin{array}{l}\text { Turkey (5\%), China (3\%), Australia (3\%), } \\
\text { India (3\%), Russia (3\%) }\end{array}$ & $17 \%$ & & \\
\hline
\end{tabular}


Appendix Table 2. (NOT INTENDED FOR PUBLICATION) Pesticides, Veterinary drugs, Plants Product Commodities, Animal Product Commodities and Country coverage of the MRL Date Base

\begin{tabular}{|c|c|c|}
\hline Pesticides & Clodinafop-propargyl & Ethoprop \\
\hline 1,3-Dichloropropene & Clofentezine & Ethoxyquin \\
\hline 1-Naphthaleneacetamide & Clomazone & Ethylene chlorohydrin \\
\hline 1-Naphthaleneacetic acid & Clopyralid & Ethylene oxide \\
\hline 2, 6-Diisopropylnaphthalene $(2$, & Cloquintocet-mexyl & Etofenprox \\
\hline 6 -DIPN) & Cloransulam-methyl & Etoxazole \\
\hline $2,4-\mathrm{D}$ & Clothianidin & Etridiazole \\
\hline $2,4-\mathrm{DB}$ & Coumaphos & Famoxadone \\
\hline Abamectin & Cryolite & Fenamidone \\
\hline Acephate & Cyazofamid & Fenarimol \\
\hline Acequinocyl & Cyclanilide & Fenbuconazole \\
\hline Acetamiprid & Cycloate & Fenbutatin-oxide \\
\hline Acetochlor & Cyflufenamid & Fenhexamid \\
\hline Acibenzolar-S-methyl & Cyfluthrin & Fenoxaprop-Ethyl \\
\hline Acifluorfen & Cyhalofop-butyl & Fenpropathrin \\
\hline Alachlor & Cymoxanil & Fenpyrazamine \\
\hline Aldicarb & Cypermethrin & Fenpyroximate \\
\hline Alpha-Cypermethrin & Cyproconazole & Fentin hydroxide \\
\hline Ametoctradin & Cyprodinil & Ferbam \\
\hline Ametryn & Cyprosulfamide & Fipronil \\
\hline Amicarbazone & Cyromazine & Flazasulfuron \\
\hline Aminopyralid & d-Phenothrin & Flonicamid \\
\hline Amitraz & DCPA & Florasulam \\
\hline Asulam & Deltamethrin & Fluazifop-P-butyl \\
\hline Atrazine & Desmedipham & Fluazinam \\
\hline Aviglycine & Diazinon & Flubendiamide \\
\hline Azinphos-methyl & Dicamba & Flucarbazone-sodium \\
\hline Azoxystrobin & Dichlobenil & Fludioxonil \\
\hline Benfluralin & Dichlormid & Flufenacet \\
\hline Benoxacor & Dichlorvos & Flufenoxuron \\
\hline Bensulfuron-methyl & Diclofop-Methyl & Flufenpyr-ethyl \\
\hline Bensulide & Dicloran & Flumetsulam \\
\hline Bentazon & Diclosulam & Flumiclorac-pentyl \\
\hline Beta-cyfluthrin & Dicofol & Flumioxazin \\
\hline Bifenazate & Dicrotophos & Fluometuron \\
\hline Bifenthrin & Difenoconazole & Fluopicolide \\
\hline Bispyribac-sodium & Diflubenzuron & Fluopyram \\
\hline Boscalid & Diflufenzopyr & Fluoride \\
\hline Bromacil & Dimethenamid & Fluoxastrobin \\
\hline Bromoxynil & Dimethenamid-P & Fluridone \\
\hline Buprofezin & Dimethoate & Fluroxypyr \\
\hline Butafenacil & Dimethomorph & Fluthiacet-methyl \\
\hline Captan & Dinotefuran & Flutolanil \\
\hline Carbaryl & Diphenylamine & Flutriafol \\
\hline Carbon disulfide & Diquat dibromide & Fluxapyroxad \\
\hline Carboxin & Disulfoton & Folpet \\
\hline Carfentrazone-ethyl & Diuron & Fomesafen \\
\hline Chlorantraniliprole & Dodine & Forchlorfenuron \\
\hline Chlorethoxyphos & Emamectin & Formetanate hydrochloride \\
\hline Chlorfenapyr & Endosulfan & Fosetyl-Al \\
\hline Chlorimuron-ethyl & Endothall & Fosthiazate \\
\hline Chlorothalonil & EPTC & Furilazole \\
\hline Chlorpropham & Esfenvalerate & Gamma Cyhalothrin \\
\hline Chlorpyrifos & Ethalfluralin & Glufosinate-ammonium \\
\hline Chlorpyrifos-methyl & Ethametsulfuron-methyl & Glyphosate \\
\hline Chlorsulfuron & Ethephon & Halosulfuron-methyl \\
\hline Clethodim & Ethofumesate & Hexazinone \\
\hline
\end{tabular}




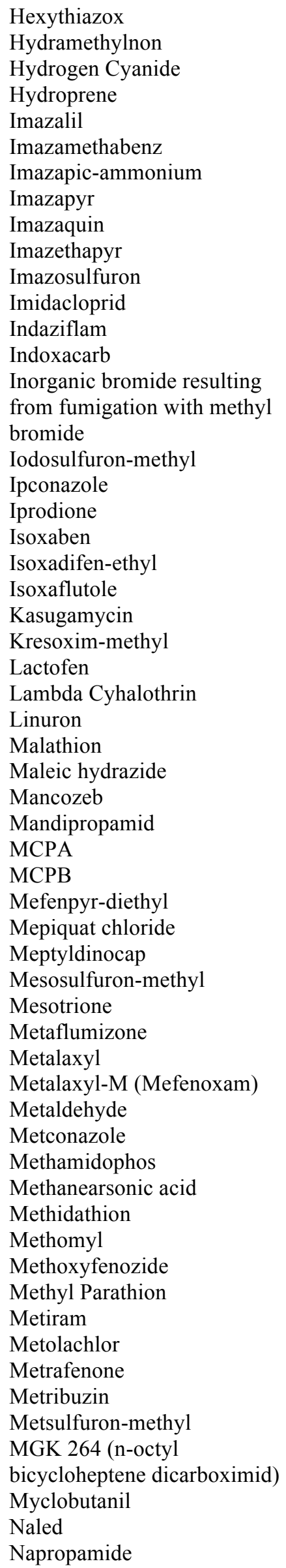

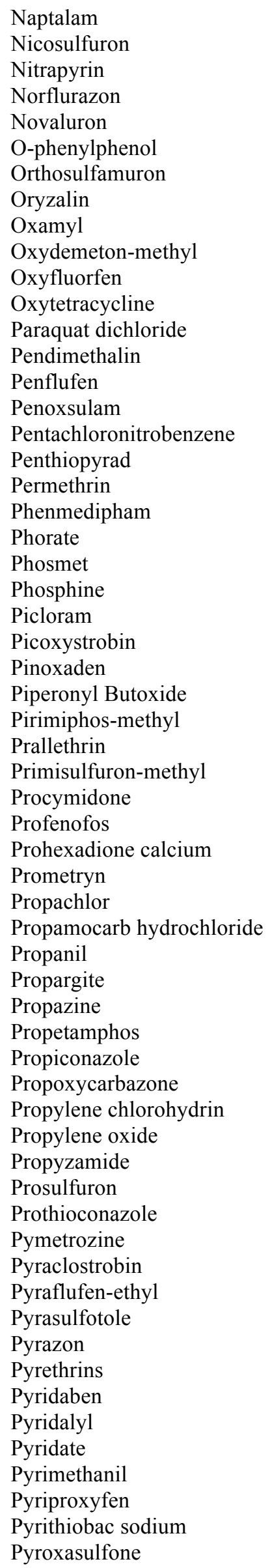

Pyroxsulam

Quinclorac

Quinoxyfen

Quizalofop-ethyl

Resmethrin

Rimsulfuron

S-metolachlor

Saflufenacil

Sedaxane

Sethoxydim

Simazine

Spinetoram

Spinosad

Spirodiclofen

Spiromesifen

Spirotetramat

Spiroxamine

Streptomycin

Sulfentrazone

Sulfosulfuron

Sulfoxaflor

Sulfur dioxide

Sulfuryl fluoride

TCMTB

Tebuconazole

Tebufenozide

Tebuthiuron

Tefluthrin

Tembotrione

Tepraloxydim

Terbacil

Terbufos

Tetrachlorvinphos

Tetraconazole

Thiabendazole

Thiacloprid

Thiamethoxam

Thiazopyr

Thidiazuron

Thiencarbazone-methyl

Thifensulfuron-methyl

Thiobencarb

Thiodicarb

Thiophanate-methyl

Thiram

Topramezone

Tralkoxydim

Tri-Allate

Triadimefon

Triadimenol

Triasulfuron

Tribenuron Methyl

Tribufos

Triclopyr

Trifloxystrobin

Trifloxysulfuron

Triflumizole

Trifluralin

Triflusulfuron-methyl

Trinexapac-ethyl 
Triticonazole

Uniconazole-P

Zeta-Cypermethrin

Zinc phosphide

Ziram

Zoxamide

\section{Veterinary drugs}

Albendazole

Altrenogest

Amoxicillin

Ampicillin

Amprolium

Apramycin

Arsenic

Bacitracin

Carbadox

Carbomycin

Ceftiofur

Cephapirin

Chlorhexidine

Chlortetracycline

Clopidol

Clorsulon

Cloxacillin

Danofloxacin

Decoquinate

Dichlorvos

Diclazuril

Dihydrostreptomycin

Doramectin

Enrofloxacin

Eprinomectin

Erythromycin

Estradiol

Ethopabate

Famphur

Fenbendazole

Fenprostalene

Florfenicol

Flunixin

Gentamicin sulfate

Halofuginone hydrobromide

Haloxon

Hygromycin B

Ivermectin

Laidlomycin

Lasalocid

Levamisole hydrochloride

Lincomycin

Maduramicin ammonium

Melengestrol acetate

Metoserpate hydrochloride

Monensin

Morantel tartrate

Moxidectin

Narasin

Neomycin

Nequinate

Nicarbazin
Novobiocin

Nystatin

Oleandomycin

Ormetoprim

Oxfendazole

Oxytetracycline

Penicillin

Piperazine

Pirlimycin

Progesterone

Pyrantel tartrate

Ractopamine

Robenidine hydrochloride

Semduramicin

Sodium sulfachloropyrazine

monohydrate

Spectinomycin

Streptomycin

Sulfabromomethazine sodium

Sulfachlorpyridazine

Sulfadimethoxine

Sulfaethoxypyridazine

Sulfamethazine

Sulfaquinoxaline

Sulfathiazole

Sulfomyxin

Testosterone propionate

Tetracycline

Thiabendazole

Tiamulin

Tilmicosin

Tripelennamine

Tulathromycin

Tylosin

Virginiamycin

Zeranol

Zilpaterol

Zoalene

\section{Plant products and} animal commodities

Acerola

Allspice

Amaranth, leafy

Ambarella

Angelica, dry

Angelica, stem and leaves

Anise, seed

Anise, star

Annatto, seed

Apple

Apricot

Apricot, Japanese

Aronia berry

Arracacha, root

Arrowroot, tuber

Artichoke, Chinese, tuber

Artichoke, globe

Artichoke, Jerusalem, tuber
Arugula

Asparagus

Atemoya

Avocado

Azarole

Balm, leaves

Balm, leaves, dry

Balsam apple

Balsam pear

Banana

Barley, grain

Basil

Basil, dry

Bean, broad (fava), succulent

Bean, dry (adzuki)

Bean, dry (field)

Bean, dry (kidney)

Bean, dry (lablab)

Bean, dry (lima)

Bean, dry (moth)

Bean, dry (mung)

Bean, dry (navy)

Bean, dry (pinto)

Bean, dry (rice)

Bean, dry (snap)

Bean, dry (tepary)

Bean, dry (urd)

Bean, dry (wax)

Bean, dry (yardlong)

Bean, dry, broad (fava)

Bean, kidney, succulent

Bean, lima, succulent

Bean, moth, succulent

Bean, mung, succulent

Bean, navy, succulent

Bean, pinto, succulent

Bean, scarlet runner, succulent

Bean, snap, succulent

Bean, wax, succulent

Bean, yardlong, succulent

Bearberry

Beet, garden, root

Beet, garden, tops

Bilberry

Blackberry

Blewitt, edible fungi

Blueberry, highbush

Blueberry, lowbush

Borage

Borage, dry

Borage, seed

Boysenberry

Broccoli

Broccoli raab

Broccoli, Chinese

Brussels sprouts

Buckwheat, grain

Buffaloberry

Bunashimeji, edible fungi

Burdock, edible, root 
Burdock, edible, tops

Burnet

Burnet, dry

Cabbage

Cabbage, Chinese, bok choy

Cabbage, Chinese, mustard, gai

choy

Cabbage, Chinese, napa

Calamondin

Calendula, seed

Camomile

Camomile, dry

Canna, edible, tuber

Cantaloupe

Caper buds

Caraway, black, seed

Caraway, seed

Cardamom, seed

Cardoon

Carrot

Carrot, tops

Cassava, root

Cassava, tops

Cassia bark

Cassia buds

Castor oil plant

Catjang, dry

Catmint (catnip)

Catmint (catnip), dry

Cattle, by products

Cattle, fat

Cattle, kidney

Cattle, liver

Cattle, meat

Cauliflower

Cavalo broccolo

Celeriac (celery root), root

Celeriac (celery root), tops

Celery

Celery seed

Celery, leaves

Celtuce

Chaya, leaves

Chayote, fruit

Chayote, root

Che

Cherimoya

Cherry, black

Cherry, capulin

Cherry, Nanking

Cherry, sweet

Cherry, tart

Chervil

Chervil, dry

Chervil, turnip, root

Chervil, turnip, tops

Chicken, byproducts

Chicken, fat

Chicken, kidney

Chicken, liver
Chicken, meat

Chickpea, dry

Chicory, root

Chicory, tops

Chilean guava

Chinese tallowtree, seed

Chinquapin

Chironja

Chive, Chinese dried leaves

Chive, Chinese, fresh leaves

Chive, dried leaves

Chive, fresh leaves

Chokecherry

Chrysanthemum, edible-leaved

Chrysanthemum, garland

Chufa, tuber

Cinnamon, bark

Citrus, citron

Clary

Clary, dry

Cloudberry

Clove buds

Coconut

Coffee bean, green

Collards

Coriander, leaf (cilantro)

Coriander, leaf (cilantro), dry

Coriander, seed

Corn salad

Corn, grain

Corn, pop

Corn, sweet

Costmary

Costmary, dry

Cottonseed

Cowpea, dry

Cowpea, succulent

Crabapple

Crambe

Cranberry

Cranberry, highbush

Cress, garden

Cress, upland

Cucumber

Cucumber, Chinese

Culantro, leaf, dry

Culantro, seed

Culantro. leaf

Cumin, seed

Cuphea, seed

Currant, black

Currant, buffalo

Currant, red, white

Curry, leaf

Curry, leaf, dry

Custard Apple

Dandelion, leaves

Date

Daylily, bulb

Dewberry
Dill

Dill seed

Dill, dry

Dock (sorrel)

Dragon fruit

Durian

Echium, seed

Eggplant

Eggplant, African

Eggplant, pea

Eggplant, scarlet

Eggs, chicken

Eggs, turkey

Elderberry

Elegans hosta

Endive (escarole)

Endive, Belgian

Enoki, edible fungi

Euphorbia, seed

European barberry

Evening primrose, seed

Feijoa (Pineapple Guava)

Fennel, bulb

Fennel, Florence, seed

Fennel, leaves

Fennel, leaves, dry

Fennel, seed

Fenugreek, seed

Fig

Flaxseed/Linseed

Fritillaria, bulb

Fritillaria, leaves

Garden huckleberry

Garlic, bulb

Garlic, great headed, bulb

Garlic, serpent, bulb

Gherkin, West Indian

Ginger, root

Ginger, white, flowers

Ginseng, root

Goji berry

Gold of pleasure

Gooseberry

Gourd, buffalo, seed

Gourd, edible (bottle)

Grains of paradise

Grape, table

Grape, wine

Grapefruit

Grapefruit, Japanese summer

Groundcherry

Guar, dry

Guava

Hare's ear mustard, seed

Hime-Matsutake, edible fungi

Hirmeola, edible fungi

Hog, by products

$\mathrm{Hog}$, fat

Hog, kidney

Hog, liver 


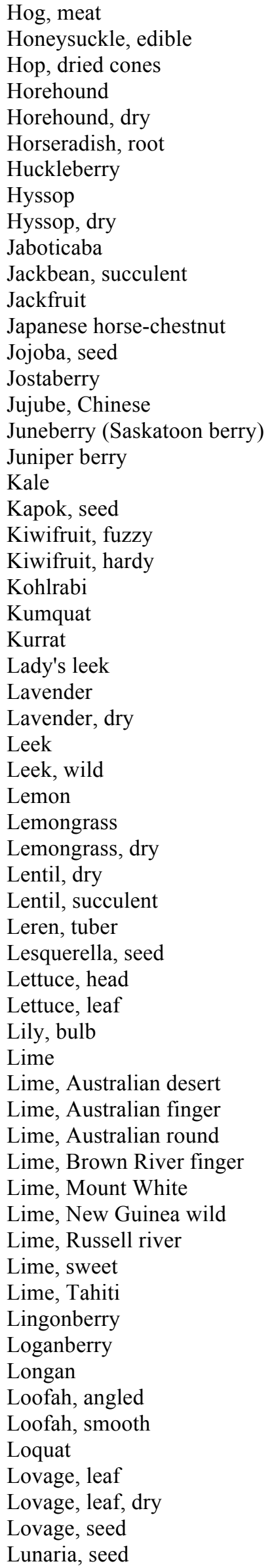

Lupin (succulent)

Lupin, dry

Lychee (litchi)

Mace

Maitake, edible fungi

Mandarin, Mediterranean

Mango

Mangosteen

Marigold (calendula) flowers

Marigold (calendula) flowers,

dry

Marjoram

Marjoram, dry

Martynia

Mayhaw

Maypop

Meadowfoam, seed

Medlar

Melon, casaba

Melon, citron

Melon, crenshaw

Melon, golden pershaw

Melon, honey ball

Melon, honeydew

Melon, mango

Melon, Persian

Melon, pineapple

Melon, Santa Claus

Melon, snake

Milk fat, cattle

Milk, cattle

Milkweed, seed

Millet, pearl, grain

Millet, proso, grain

Mizuna

Morel, edible fungi

Mountain pepper berries

Mulberry

Muntries

Mushroom, button

Mushroom, Chinese

Mushroom, oyster

Mushroom, reishi

Mushroom, Rodman's agaricus

Mushroom, shiitake

Muskmelon

Mustard greens

Mustard seed, black

Mustard seed, field

Mustard seed, Indian (brown)

Mustard seed, white/yellow

Mustard spinach

Nameko, edible fungi

Naranjilla

Nasturtium, garden leaves

Nasturtium, garden leaves, dry

Native currant

Nectarine

Net Bearing, edible fungi

Niger, seed
Nut, African nut-tree

Nut, almond

Nut, beech

Nut, Brazil

Nut, Brazilian pine

Nut, bunya

Nut, bur oak

Nut, butter

Nut, cajou

Nut, candle

Nut, cashew

Nut, chestnut

Nut, coquito

Nut, dika

Nut, ginkgo

Nut, Guiana chestnut

Nut, hazelnut (filbert)

Nut, heartnut

Nut, hickory

Nut, macadamia

Nut, Mongongo

Nut, monkey puzzle

Nut, monkey-pot

Nut, okari

Nut, pachira

Nut, peach palm

Nut, pecan

Nut, pequi

Nut, pili

Nut, pine

Nut, pistachio

Nut, sapucaia

Nut, tropical almond

Nut, walnut, black

Nut, walnut, English (Persian)

Nut, yellowhorn

Nutmeg

Oat, grain

Oil radish, seed

Okra

Olive, table

Onion, Beltsville bunching

Onion, bulb

Onion, Chinese, bulb

Onion, fresh

Onion, green

Onion, macrostem

Onion, pearl

Onion, potato, bulb

Onion, tree, tops

Onion, Welsh, tops

Orach

Orange, sour

Orange, sweet

Orange, tachibana

Orange, trifoliate

Palm heart

Palm heart, leaves

Papaya

Parsley, dry 
Parsley, fresh

Parsley, turnip-rooted

Parsnip, root

Parsnip, tops

Partridgeberry

Passion fruit

Pawpaw

Pea, blackeyed, succulent

Pea, dry (blackeyed)

Pea, dry (crowder)

Pea, dry (dwarf)

Pea, dry (English)

Pea, dry (field)

Pea, dry (garden)

Pea, dry (green)

Pea, dry (pigeon)

Pea, dry (snow)

Pea, dry (southern)

Pea, dry (sugar snap)

Pea, dwarf, succulent

Pea, English, succulent

Pea, field, succulent

Pea, garden, succulent

Pea, green, succulent

Pea, pigeon, succulent

Pea, snow, succulent

Pea, southern, succulent

Pea, sugar snap, succulent

Peach

Peanut

Pear

Pear, Asian

Pennyroyal

Pennyroyal, dry

Pepino

Pepper leaf

Pepper, bell

Pepper, black

Pepper, non-bell

Pepper, white

Peppermint

Peppermint, dry

Peppermint, oil

Persimmon, American

Persimmon, Japanese

Phalsa

Pincherry

Pineapple

Plantain

Plum, American

Plum, beach

Plum, Canada

Plum, cherry

Plum, chickasaw

Plum, damson

Plum, Japanese

Plum, Klamath

Plum, prune, dry

Plum, prune, fresh

Plumcot
Pom Pom, edible fungi

Pomegranate

Poppy, seed

Potato

Prickly pear cactus, fruit

Prickly pear cactus, pads

Pummelo

Pumpkin

Purslane, garden

Purslane, winter

Quince

Quince, Chinese

Quince, Japanese

Radicchio (red chicory)

Radish, oriental (daikon), root

Radish, oriental (daikon), tops

Radish, root

Radish, tops

Raisin

Rape greens

Rape seed (canola)

Raspberry, black/red

Raspberry, wild

Rhubarb

Riberry

Rice, grain

Rice, wild, grain

Rose hips

Roselle, buds

Rosemary

Rosemary, dry

Rue

Rue, dry

Rutabaga, root

Rutabaga, tops

Rye, grain

Safflower, seed

Saffron

Sage

Sage, dry

Salal

Salsify, black, root

Salsify, black, tops

Salsify, root

Salsify, Spanish, root

Salsify, tops

Sapodilla

Sapote, black

Sapote, mammey

Sapote, white

Satsuma mandarin

Savory, summer

Savory, summer, dry

Savory, winter

Savory, winter, dry

Schisandra berry

Sea buckthorn

Serviceberry

Sesame, seed

Shallot, bulb
Shallot, fresh leaves

Sheep, by products

Sheep, fat

Sheep, kidney

Sheep, liver

Sheep, meat

Shimeji, edible fungi

Skirret, root

Sloe

Sorghum, grain

Soursop

Soybean

Soybean (immature seed)

Spanish lime

Spearmint

Spearmint, dry

Spearmint, oil

Spinach

Spinach, New Zealand

Spinach, vine

Squash, summer (crookneck)

Squash, summer (scallop)

Squash, summer (straightneck)

Squash, summer (vegetable

marrow)

Squash, summer (zucchini)

Squash, winter (acorn)

Squash, winter (butternut)

Squash, winter (calabaza)

Squash, winter (hubbard)

Squash, winter (spaghetti)

Star apple

Starfruit

Stokes aster, seed

Strawberry

Stropharia, edible fungi

Sugar apple

Sugar cane

Sugar, beet, roots

Sugar, beet, tops

Sunberry

Sunflower, seed

Surinam cherry

Sweet bay

Sweet bay, dry

Sweet potato

Sweet potato, tops

Sweet rocket, seed

Swiss chard

Swordbean

Tallowwood, seed

Tamarind

Tangelo

Tangerine (mandarin)

Tangor

Tanier, corm

Tanier, tops

Tansy

Tansy, dry

Taro (dasheen), corm 


\begin{tabular}{|c|c|c|}
\hline Tarragon & Belgium & Saudi Arabia \\
\hline Tarragon, dry & Bermuda & Singapore \\
\hline Tea oil plant & Brazil & South Africa \\
\hline Tea, leaves & Brunei & Spain \\
\hline Tejocote & Cambodia & Sri Lanka \\
\hline Teosinte, grain & Canada & St. Lucia \\
\hline Thyme & Cayman Islands & Sweden \\
\hline Thyme, dry & Chile & Switzerland \\
\hline $\mathrm{Ti}$, leaves & China & Taiwan \\
\hline $\mathrm{Ti}$, roots & Colombia & Thailand \\
\hline Tomatillo & Costa Rica & Trinidad and Tobago \\
\hline Tomato & Cuba & Tunisia \\
\hline Tomato, bush & Customs Union & Turkey \\
\hline Tomato, currant & Denmark & United Arab Emirates \\
\hline Tomato, tree & Dominican Republic & United Kingdom \\
\hline Triticale, grain & Ecuador & Venezuela \\
\hline Truffle, edible fungi & Egypt & Vietnam \\
\hline Turkey, byproducts & El Salvador & \\
\hline Turkey, fat & Finland & \\
\hline Turkey, kidney & France & \\
\hline Turkey, liver & French Pacific Islands & \\
\hline Turkey, meat & French West Indies & \\
\hline Turmeric, root & Germany & \\
\hline Turnip, root & Greece & \\
\hline Turnip, tops & Guatemala & \\
\hline Ugli/Uniq fruit & Gulf Cooperation Council & \\
\hline Vanilla, beans & Haiti & \\
\hline Vernonia, seed & Honduras & \\
\hline Wasabi, roots & Hong Kong & \\
\hline Watercress & Iceland & \\
\hline Watermelon & India & \\
\hline Wax jambu & Indonesia & \\
\hline Waxgourd & Ireland & \\
\hline Wheat, grain & Israel & \\
\hline White jelly fungi & Italy & \\
\hline Wintergreen, leaves & Jamaica & \\
\hline Wintergreen, leaves, dry & Japan & \\
\hline Woodruff & Jordan & \\
\hline Woodruff, dry & Kenya & \\
\hline Wormwood & Korea & \\
\hline Wormwood, dry & Kuwait & \\
\hline Yam bean (jicama), root & Lebanon & \\
\hline Yam, true, tops & Malaysia & \\
\hline Yam, true, tuber & Mexico & \\
\hline Youngberry & Morocco & \\
\hline & Netherlands & \\
\hline Countries & Netherlands Antilles & \\
\hline United States & Nevis & \\
\hline Codex & New Zealand & \\
\hline European Union & Nicaragua & \\
\hline Albania & Norway & \\
\hline Algeria & Oman & \\
\hline Angola & Pakistan & \\
\hline Antigua and Barbuda & Panama & \\
\hline Argentina & Peru & \\
\hline Australia & Philippines & \\
\hline Bahamas & Poland & \\
\hline Bahrain & Portugal & \\
\hline Bangladesh & Qatar & \\
\hline Barbados & Russia & \\
\hline
\end{tabular}

